\title{
CURRENT ANATOMICAL RESEARCH IN LILIACEAE, AMARYLLIDACEAE AND IRIDACEAE*
}

\author{
D.F. CUTLER AND MARY GREGoRY \\ (Accepted for publication 20.9.1982)
}

\begin{abstract}
Cutler, D.F. and Gregory, Mary (Jodrell Laboratory, Royal Botanic Gardens, Kew, Richmond, Surrey, England) 1983. Current anatomical research in Liliaceae, Amaryllidaceae and Iridaceae. Telopea 2(4): 425-452, Fig.1-An annotated bibliography is presented covering literature over the period 1968 to date. Recent research is described and areas of future work are discussed.
\end{abstract}

\section{INTRODUCTION}

In this article, the literature for the past twelve or so years is recorded on the anatomy of Liliaceae, Amaryllidaceae and Iridaceae and the smaller, related families, Alliaceae, Haemodoraceae, Hypoxidaceae, Ruscaceae, Smilacaceae and Trilliaceae. Subjects covered range from embryology, vegetative and floral anatomy to seed anatomy.

A format is used in which references are arranged alphabetically, numbered and annotated, so that the reader can rapidly obtain an idea of the range and contents of papers on subjects of particular interest to him. The main research trends have been identified, classified, and check lists compiled for the major headings.

Current systematic anatomy on the 'Anatomy of the Monocotyledons' series is reported. Comment is made on areas of research which might prove to be of future significance.

\section{CURRENT RESEARCH}

Work on the taxonomy of Liliaceae and their close relatives is entering an interesting period. Now that it is well recognised that a synthetic approach to classification is necessary (e.g. Huber 1977; Thorne 1976, 1977; Cronquist 1968; Traub 1975; Clifford 1977; Dahlgren 1975, 1977, 1980) there are signs of progress.

Of course, the specialists in disciplines like anatomy, palynology and phytochemistry will be hard to satisfy. They will probably feel that undue emphasis is still given to subjects other than their own. Having said this, it is perfectly clear to the plant anatomist that those attempting synthesis of data are hampered by incomplete or unconfirmed observations in the anatomical realm. It is evident that there is still scope for careful, accurate recording of anatomical data for systematic purposes. Attempts to construct schemes purported to show affinities between genera in Liliaceae, Amaryllidaceae, Iridaceae and related small families will inevitably be only partly successful until the anatomical data are presented in a comprehensive way. There are numerous papers which deal with the anatomy of one or two genera, or even several species within a genus, but few that make a wide survey. Some of these specialized articles are very helpful, e.g. Niehaus (1980) on the Brodiaea complex, De Vos (1970-9) on Romulea and other Iridaceae and Artyushenko's series of papers

\footnotetext{
* Paper presented at XIII International Botanical Congress, Sydney. 1981. Symposium: Systematics and Evolution of the Liliiflorae.

Convenors: $\mathrm{H}$. Huber and $\mathrm{Hj}$. Eichler.
} 
on Galanthus and Zephyranthes (Artyushenko 1969, 1974, 1980; Artyushenko \& Dzidziguri, 1979). But there are few recent comprehensive anatomical reviews available. Of these Artyushenko (1970) has surveyed the morphology and anatomy of several genera of Amaryllidaceae, and Ambrose (1980) has written on the Melanthioideae using numerical analyses of morphological and anatomical data.

During the past twelve years progress has been made towards a volume in the series 'Anatomy of the Monocotyledons' (ed. C.R. Metcalfe) which will include Liliaceae, Amaryllidaceae, Iridaceae and smaller related families. The volume will be an example of international co-operation. Direct contributions to the descriptions on Amaryllidaceae will come from Dr N.L. de Menezes (Brazil) and Dr S. Arroyo (Argentina). Dr de Menezes (1980) has made observations on the relationships between Velloziaceae and Amaryllidaceae. Dr Arroyo has concentrated on affinities between members of the family from S. America and S. Africa (1981).

For the Liliaceae, Ambrose's (1980) paper will provide the basis for the Melanthioideae, and Cutler has been concentrating on other groups. Much of Cutler's published work has been on the Aloineae, in particular on leaf surface studies (Cutler 1972, 1978, 1979, Cutler \& Brandham 1977, Cutler et al. 1980). There are also contributions by Dr Baijnath (S. Africa) on Bulbine and its relatives and Kniphofia (Baijnath 1977, 1980).

The Iridaceae are currently being examined anatomically by Dr P. Rudall (Kew) and Iris by Mr Wu Gi-gen (China). In this family, leaf transverse sectional outlines and sclerenchyma distribution are of particular interest. Also, the range of vascular bundle types may provide data of taxonomic significance.

Miss M. Gregory is working on the Alliaceae, where the arrangement of the vascular bundles and position of laticifers in the leaf are of use taxonomically.

Mesophyll in many of the genera of all three major families may provide characters of some importance. It is known that mesophyll, in particular the number of palisade layers, can be influenced markedly by leaf environment. This has tended to make anatomists cautious about using mesophyll features as potential taxonomic characters, and may explain why this tissue is relatively neglected in the literature on Liliales. Cutler's studies of a wide range of genera indicate that, when observed in L.S., otherwise undistinguished 'rounded' mesophyll cells may have a characteristic appearance. Further, additional and often quite striking features may be seen if the mesophyll is viewed paradermally-preferably through the epidermis, since attempts to cut paradermal sections may disarrange the cells (Fig. 1).

In addition to 'classical' systematic studies, there are other areas of work which will all contribute to a greater understanding of interrelationships between these families. Cheadle and colleagues have been making a long series of studies on vessel elements (1968-71). The types and their distribution, whether in root only, or root and stem, or all vegetative parts are of considerable interest, and may enable us to deduce the 'direction' of evolution for some groups. Huber has made extensive studies of seeds (1969) and those results and other observations have enabled him to formulate ideas on relationships within his Liliales (1977). The phylogenetic significance of the structure of the floral nectary in monocotyledons has been discussed by Daumann (1970), and that of embryos by Khokhryakov (1971, 1975). Behnke's (1972) work on sieve-tube plastids has drawn evidence of inter-relationships from a new source which has proved of considerable interest.

Kaplan has made extensive developmental studies both on the nature of the monocotyledonous leaf (1973) and of unifacial leaves in monocotyledons (1975). Guédès (1972, 1980) and Bugnon \& Mbaya (1976) are also involved in this area of research. This work is most important, since it aids an understanding of the nature of the organs we are dealing with, and complements studies on comparative anatomy. Other developmental studies have concentrated on branching, vascular systems and intercalary meristems (e.g. Fisher \& French 1976, 1978).

Examples of the interest in bulb and inflorescence morphology and anatomy can be found in the works of Ekberg (1972), Müller-Doblies (1971, 1977, Müller-Doblies, D. \& U. 1978) and Baranova (1976). Sterling, from 1972 onwards, has produced a 
series of papers concerned with the anatomy of carpels in the Liliacae, and the floral vascular system of a number of members of this family has been studied by Utech (1978-9, Utech \& Kawano 1975-1980).

Phytochemical papers are, on the whole, outside the range of this review, but mention should be made of works on crystal types and their distribution, e.g. Samara \& Terpó (1980) and Amico et al. (1977, 1979).

Few recent accounts exist about the importance of stomatal types within the monocotyledons. Tomlinson (1974) wrote on this topic in general, but most workers deal with rather well-defined, small groups, e.g. Bresky (1975), who reported on stomatal types in some South American members of Amaryllidaceae, Alstroemeriaceae, Iridaceae and Liliaceae, Pande (1980), who worked on Iridaceae, Qualo (1976), who examined the stomata of $27 \mathrm{spp}$. of Haworthia, and Shah \& Gopal (1970), who studied various species of Amaryllidaceae.

Embryological studies are very time-consuming, and have tended to be fewer in number than those for most other anatomical aspects during the past twelve years. Examples include those of Björnstad (1970), Cave (1974, 1975), Lakshmanan \& Philip (1971), and Sokolowska-Kulczycka (1973-80), but all seen by the present authors are listed in the annotated bibliography, together with papers on all the other aspects mentioned above, as well as some of which space would not permit discussion.

\section{FUTURE RESEARCH}

Although classical studies can be rather drawn out and the routine discipline of making careful observations and records somewhat daunting, undoubtedly they will be of increasing importance in the next few years, as data are gathered together, gaps in knowledge found and filled. The scattered nature of current information-and the surprising lack of it on certain groups-make this task essential.

$H$. Rasmussen (in preparation) has demonstrated how essential it is to study stomatal development in each species before data are incorporated into systematic and phylogenetic studies. Purely descriptive studies on mature stomata have value at the diagnostic level, and will continue to be published, but the additional information to be obtained for the little extra work on development is well worthwhile. Since most monocot leaves have a basal meristem, this is relatively easy to do from live material.

Other developmental studies are normally very time-consuming. This limits their application in systematics, but not their importance. In particular, studies on branching systems and entire vascular systems show considerable promise.

Recent discussion on the value of studies on flower development (see Kaplan 1971) have aroused interest in this field. Carpel and inflorescence vasculature have yielded very valuable data in the past, and, with due care over interpretation, should continue to do so.

The potential of comparative, developmental embryological studies in the Liliales has by no means been exhausted. Seed and seedling anatomy have also more to yield to the research worker.

In dicotyledons, venation patterns (Hickey 1980) have extensive taxonomic and phylogenetic implications. There is an undoubted potential for comparable work in the monocotyledons.

Recent studies on leaf surfaces with the SEM (Cutler et al. 1980) have demonstrated the wealth of new characters to be found which are of taxonomic interest. It is not clear yet whether these will have taxonomic significance beyond the generic level, or whether they will prove to be of more interest to the student of ecological anatomy. Consequently more surveys and experimental studies could yield important results. Similarly, petal surface features are very well demonstrated by the SEM (Stirton 1981), and here is an almost virgin field of study, since Barthlott \& Ehler have looked at only a few monocot petals in their 1977 paper. Huber's (1969) survey of seed anatomy could be extended by use of the SEM. Vessel elements also show up very clearly in the SEM. 


\section{ANNOTATED BIBLIOGRAPHY}

All of the references have been seen in the original, except where abstracting sources are cited in square brackets.

The following abbreviations are used:

$\begin{array}{ll}\text { Alliaceae } & \text { All. } \\ \text { Amaryllidaceae } & \text { Amar. } \\ \text { Haemodoraceae } & \text { Haem. } \\ \text { Hypoxidaceae } & \text { Hypox. } \\ \text { Iridaceae } & \text { Irid. } \\ \text { Liliaceae } & \text { Lili. } \\ \text { Ruscaceae } & \text { Rusc. } \\ \text { Smilacaceae } & \text { Smil. } \\ \text { Trilliaceae } & \text { Trill. } \\ \text { LM } & \text { light microscopy } \\ \text { SEM } & \text { scanning electron microscopy } \\ \text { TEM } & \text { transmission electron microscopy }\end{array}$

For subject index see p.451.

1. Abbasova, V.S. \& Ibadov, O.V. (1974) [Anatomy of some wild, decorative species of Liliaceae.] Izv. Akad. Nauk Azerb. SSR, Biol. Nauk (5-6): 15-21. [Russian] Mainly Tulipa, also Fritillaria, Muscari, Ornithogalum. Leaf.

2. Altamura, L. \& Ricci, I. (1978-9) [1979] Cariologia e sistematica di Hermodactylus tuberosus Mill. Annali Bot. 37, 1-13. Irid. Leaf anatomy, p.6.

3. Ambrose, J.D. (1980) A re-evaluation of the Melanthioideae (Liliaceae) using numerical analyses. pp.65-81 in: Petaloid monocotyledons (eds. Brickell, C.D., Cutler, D.F. \& Gregory, M.) Academic Press: London. Aletris, Amianthium, Harperocallis, Lophiola, Melanthium, Metanarthecium, Narthecium, Nietneria, Pleea, Stenanthium, Tofieldia, Uvularia, Veratrum, Xerophyllum, Zigadenus. Includes characters of leaf and root anatomy.

4. Amico, A. \& Stefanizzi, L. (1980) Struttura, embriologia, localizzazione citochimica degli alcaloidi di Nerine undulata Herb. Fitoterapia 51, 211-22. Amar. Anatomy of all parts; embryology.

5. Amico, A., Stefanizzi, L. \& Bruno, S. (1979) Osservazioni morfologiche, estrazione e localizzazione di alcaloidi in Clivia miniata Regel. Fitoterapia 50, 157-65. Amar. Notes on embryology and vegetative anatomy.

6. Amico, A., Stefanizzi, L., Bruno, S. \& Bonvino, V. (1977) Localizzazione citochimica della licorina in bulbi di Amaryllis belladonna L. Fitoterapia 48, 60-7. Amar. Bulb anatomy.

7. Andreata, R.H.P. (1979) Smilax spicata Vellozo (Smilacaceae)-considerações taxonômicas. Rodriguesia 31 (50) 105-15. Leaf epidermis and venation.

8. Andreata, R.H.P. (1980) Smilax Linnaeus (Smilacaceae). Ensaio para uma revisão das espécies brasileiras. Arq. Jard. bot. Rio de Janeiro 24, 179-301. [English summary 219.] $12 \mathrm{spp}$. Leaf epidermis and venation.

9. Andreeva, I.I. (1979) [Morphogenesis of some bulbous South African representatives of the family Iridaceae.] Byull. Glavn. Bot. Sada, No.111, 31-9 [Russian] Lepeyrousia, Tritonia.

10. Arroyo, S.C. (1981) Systematic anatomical studies on Amaryllidaceae including morphological, cytological and phytogeographical considerations. Ph.D. thesis: Univ. Reading. 238 pp. Anatomy of 25 genera. Mainly leaf, also peduncle, bulb, rhizome, root. Includes SEM studies.

11. Artyushenko, Z.T. (1969) Critical review of the genus Galanthus L. Plant Life 25, 137-52. Amar. Leaf anatomy, 2 groups.

12. Artyushenko, Z.T. (1970) The genus Ungernia Bge. Plant Life (Amaryllis Year Book) 26, 173-88. Amar. 6 spp. Bulb scale anatomy. 
13. Artyushenko, Z.T.(1970) Amarillisovie (Amaryllidaceae Jaume St.-Hilaire). SSSR. Morfologiya, sistematika i ispolzovanie. Izdat. Nauka: Leningrad. 178 pp. [Russian]. Leaf and stem anatomy, bulb morphology. Galanthus, Ixiolirion, Leucojum, Narcissus, Pancratium, Sternbergia, Ungernia.

14. Artyushenko, Z.T. (1974) Galanthus L. (Amaryllidaceae) in Greece. Ann. Mus. Goulandris 2, 9-21. [Eng.] Taxonomy; leaf epidermis.

15. Artyushenko, Z.T. (1980) Some studies on the vegetative anatomy of Galanthus and Zephyranthes (Amaryllidaceae) and their taxonomic significance. pp.83-8 in: Petaloid monocotyledons (eds. Brickell, C.D., Cutler, D.F. \& Gregory, M.) Academic Press: London. Leaf anatomy. Also mentioned: Crinum, Haemanthus, Ixiolirion, Narcissus, Sternbergia, Ungernia, Vallota. Zephyranthes candida transferred to Argyropsis.

16. Artyushenko, Z.T. \& Dzidziguri, L.K. (1979) [The significance of anatomical structure of vegetative organs in the genus Zephyranthes Herb. (Amaryllidaceae Jaume) for their taxonomy.] Bot. Zh. SSSR 64, 405-9. [Russian]. Also Habranthus, Pyrolirion. Z. candida = Argyropsis. Leaf and bulb scale anatomy.

17. Azizbekova, N.Sh. \& Milyaeva, E.L. (1978) [Ontogenesis of Crocus sativus and changes in the stem apices.] Ontogenez 9, 309-14. [Russian; English summary] Irid. Transition from vegetative to reproductive apex.

18. Bahadur, B. (1976) On the occurrence of stomata on the inner ovary wall of Belamcanda chinensis DC. Curr. Sci. 45, 65-7. [Bull. Signal., CNRS 370, 37 (1976) No.7036.] Irid.

19. Baijnath, H. (1977) Taxonomic studies in the genus Bulbine Wolf, sensu lat. Thesis: Univ. Reading. T.S. 444 pp. Lili. Includes leaf anatomy, LM and SEM. Also Jodrellia.

20. Baijnath, H. (1978) A new species of Bulbine (Liliaceae) from Australia. Brunonia 1, 117-20. SEM seeds of $3 \mathrm{spp}$.

21. Baijnath, H. (1980) A contribution to the study of leaf anatomy of the genus Kniphofia Moench (Liliaceae). pp. 89-103 in: Petaloid monocotyledons (eds. Brickell, C.D., Cutler, D.F. \& Gregory, M.) Academic Press: London. $18 \mathrm{spp}$. and hybrids. Also Notosceptrum. LM \& SEM.

22. Baijnath, H. \& Perry, P. (1980) Preliminary observations of leaf surface structures in Eriospermum Jacq. Proc. Electron Microsc. Soc. S. Afr. 10, 39-40. Lili. SEM.

23. Bal, A.K. (1973) Studies in the quiescent root meristem of the bulb of Allium cepa L.: fine structure and DNA synthesis. Dev. Growth Differ. 15, 225-39. [Biol. Abstr. 58 (1974) No.33897.] All. TEM.

24. Bal, A.K. \& Payne, J.F. (1971) Endoplasmic reticulum activity and cell wall breakdown in quiescent root meristems of Allium cepa L. $Z$. Pflanzenphysiol. 66, 265-72. All. TEM.

25. Baranova, M.V. (1971) [The morphogenesis of the bulbs of lilies.] Bot. Zh. SSSR 56, 1593-1604. [Russian; English summary] Lili. Lilium.

26. Baranova, M.V. (1973) [On the formation of flowers in stem bulblets of Lilium.] Bot. Zh. SSSR 58, 890-3. [Russian] Lili. Morphology only.

27. Baranova, M.V. (1974) [The types of seed germination and development of seedlings in Lilium L. species.] Bot. Zh. SSSR 59, 1045-55. [Russian] Lili. Morphology only.

28. Baranova, M.V. (1976) [Peculiarities of bulb morphology and bulb formation in some African Liliaceae.] Bot. Zh. SSSR 61, 1696-1708. [Russian; English summary] Bowiea, Dipcadi, Drimiopsis, Eucomis, Galtonia, Lachenalia, Ledebouria, Neobakeria, Ornithogalum, Veltheimia.

29. Barradas, M.M. \& Figueiredo, R. de C.L. (1974) Contribuição ao estudo da nervação foliar de plantas dos Cerrados-Liliaceae, subfamilia Smilacoideae. Hoehnea 4, 1-11. Smil. Smilax 6 spp.

30. Barthlott, W. \& Ehler, N. (1977) Raster-Elektronenmikroskopie der EpidermisOberflächen von Spermatophyten. Trop. Subtrop. Pflwelt 19, 367-467. 
General survey. Includes Amar., Hypox., Lili. (fig. 27, Scilla petal). SEM cuticle of shoots, leaves, perianths, seeds.

31. Behnke, H.-D. (1972) Sieve-tube plastids in relation to angiosperm systematics-an attempt towards a classification by ultrastructural analysis. Bot. Rev. 38, 155-97. Review of literature. Includes Amar., Lili., Rusc.

32. Bell, W.D. \& Stiles, H.D. (1974). Stomatal size as an indication of Amaryllis polyploidy. Plant Life 30, 89-90. Amar.

33. Belyanina, N.B. \& Krylova, I.L. (1971) [Structure of epidermis in some species of Ornithogalum L.] Byull. Mosk. Obshch. Ispyt. Prir., Otd. biol. 76 (6), 93-9 [Russian; English summary.] Lili. Bulb scales. 13 spp.

34. Belyanina, N.B. \& Krylova, I.L. (1976) [Anatomical and morphological characters of the vegetative organs of Ornithogalum species.] Byull. Mosk. Obshch. Ispyt. Prir., Otd. biol. 81 (5), 69-83. [Russian; English summary.] Lili. Bulb, leaf 21 spp. Key.

35. Belyanina, N.B. \& Proskuryakova, G.M. (1978) [Systematics of the hyacinths of Turkmenia.] Nauch. Dokl. vyssh. Shk., biol. Nauki (1), 98-107. [Russian] [Biol. Abstr. 67 (1979) No. 20277.] Lili. Hyacinthella, Hyacinthus.

36. Berg, R.Y. (1978) Development of ovule, embryo sac, and endosperm in Brodiaea (Liliales). Norw. J. Bot. 25, 1-7. All.

37. Björnstad, I.N. (1970) Comparative embryology of Asparagoideae-Polygonateae, Liliaceae. Nytt Mag. Bot. 17, 169-207. Clintonia, Convallaria, Disporum, Maianthemum, Polygonatum, Smilacina.

38. Boer-de-Jeu, M.J. de (1978) Ultrastructural aspects of megasporogenesis and initiation of megagametogenesis in Lilium. Bull. Soc. Bot. Fr. 125, Act. Bot. 1/2, 175-81. Lili. TEM.

39. Bonfante Fasolo, P., Scannerini, S. \& Arborino, M. (1976) "Transfer cells" nelle radici di Ornithogalum umbellatum L. Allionia 21, 45-52. [Bull. signal., CNRS 370, 39 (1978) No. 2751] Lili. TEM.

40. Bonnet, B. (1976) Etude de la croissance de la feuille du poireau (Allium porrum L., cultivars Blue de Solaise et Long de Mézières). Modifications expérimentales. Thèse: Besançon. 110 pp. [Bull. signal., CNRS 370, 38 (1977) No. 5565.] All. LM, SEM. Leaf anatomy and relations with parasite.

41. Bonnet, B. \& Boscher, J. (1978) Importance écologique des structures superficielles de la feuille du poireau (Allium porrum L.) pour l'un de ses consommateurs, la teigne (Acrolepiopsis assectella Zell.). C.r. Acad. Sci., Paris, D, 287, 479-82. All. SEM cuticle.

42. Bothmer, R. von (1974) Studies in the Aegean flora. XXI Biosystematic studies in the Allium ampeloprasum complex. Opera Bot., Lund, No. 34, 1-104. All. Morphology. SEM tepals and seeds.

43. Bouman, F. (1974) Developmental studies of the ovule, integuments and seed in some angiosperms. Theses: Univ. Amsterdam. 180 pp. Los: Naarden. Includes Lili. Lilium.

44. Brandham, P.E. \& Cutler, D.F. (1978) Influence of chromosome variation on the organisation of the leaf epidermis in a hybrid Aloe (Liliaceae). Bot. J. Linn. Soc. 77, 1-16. SEM cuticle.

45. Bresky, G. de N. (1975) Alcance taxonomico del estudio de los estomas en Corolliferae chilenas. Anal. Mus. Hist. nat. Valparaiso 8, 100-7. Includes All. Allium, Leucocoryne, Miersia, Nothoscordum. Irid. Libertia, Sisyrinchium.

46. Brunaud, A. \& Turlier, M.-F. (1971) [1972]. Structures monopodiale et sympodiale: étude de quelques exemples d'interprétation controversée. Bull. Soc. Bot. Fr. 118, 543-60. Includes Amar. Galanthus shoot apex.

47. Brunkener, L. (1975) Beiträge zur Kenntnis der frühen Mikrosporangienentwicklung der Angiospermen. Svensk bot. Tidskr. 69, 1-27. Includes Lili. Hosta, Ornithogalum. 
48. Bugnon, F. \& Mbaya, N. (1976) La feuille "unifaciale" des monocotylédones et son interprétation. Cas de l'Iris germanica L. C. r. Acad. Sci., Paris. D, 283, 33-6. Irid. Development.

49. Bugnon, F. \& Mbaya, N. (1976) La feuille "unifaciale"' des monocotylédones et son interprétation. Cas de l'Allium cepa L. C.r. Acad. Sci., Paris, D, 282, 711-14. All. development.

50. Bugnon, F. \& Mbaya, N. (1976) La feuille "unifaciale" des Monocotylédones et son interprétation. Cas de l'Allium porrum. C. r. Acad. Sci., Paris, D, 282, 1507-10. All. development.

51. Burtt, B.L. (1970) The evolution and taxonomic significance of a subterranean ovary in certain monocotyledons. Israel J. Bot. 19, 77-90. Includes Amar. Apodolirion, Crinum, Crocopsis, Gethyllis, Haylockia, Sternbergia. Irid. Crocus, Romulea, Syringodea. Lili. Bulbocodium, Colchicum, Merendera.

52. Cassagne, C. \& Lessire, R. (1975) Mouvements des cires entre la couche épicuticulaire et la cellule d'épiderme d'Allium porrum L. C.r. Acad. Sci., Paris, D. 280, 2537-40. [Bull. signal., CNRS 370, 36 (1975) No. 9338.] All.

53. Cave, M.S. (1974) Female gametophytes of Chlorogalum and Schoenolirion (Hastingsia). Phytomorphology 24, 56-60. Lili.

54. Cave, M.S. (1975) Embryological studies in Stypandra (Liliaceae). Phytomorphology 25, 95-9.

55. Cheadle, V.I. (1968) [1969] Vessels in Haemodorales. Phytomorphology 18, 412-20. Haem. Anigozanthos, Blancoa, Conostylis, Dilatris, Haemodorum, Lachnanthes, Lanaria, Macropidia, Phlebocarya, Tribonanthes, Wachendorfia, Xiphidium. Hypox. Campynema, Curculigo, Hypoxis, Pauridia.

56. Cheadle, V.I. (1969) Vessels in Amaryllidaceae and Tecophilaeaceae. Phytomorphology 19, 8-16. All. 5 genera. Amar. 31 genera.

57. Cheadle, V.I. (1970) Vessels in Pontederiaceae, Ruscaceae, Smilacaceae and Trilliaceae. pp. 45-50 in: New research in plant anatomy (eds. Robson, N.K.B., Cutler, D.F. \& Gregory, M.) Academic Press. Rusc. Danae, Ruscus, Semele. Smil. Heterosmilax, Rhipogonum, Smilax. Trill. Medeola, Paris, Scoliopus, Trillium.

58. Cheadle, V.I. \& Kosakai, H. (1971) [1972] Vessels in Liliaceae. Phytomorphology 21, 320-33. Numerous genera. Vessels in all roots; some stems; no leaves, bulbs, rhizomes. Discusses relationships with Amar., Irid., Trill.

59. Chen, S. (1971) Developmental morphology of the flower in Narcissus. Ann. Bot. 35, 881-90. Amar.

60. Chernykh, N.A. (1972) [Frequency and distribution of stomas in Convallaria with respect to the taxonomy of the genus.] Bot. Zh. SSSR 57, 971-7. [Russian] Lili.

61. Clarke, A.E., Considine, J.A., Ward, R. \& Knox, R.B. (1977) Mechanism of pollination in Gladiolus: roles of the stigma and pollen-tube guide. Ann. Bot. 41, 15-20. Irid. SEM.

62. Clifford, H.T. (1970) Monocotyledon classification with special reference to the origin of the grasses (Poaceae). pp.25-34 in: New research in plant anatomy (eds. Robson, N.K.B., Cutler, D.F. \& Gregory, M.) Academic Press. Includes Amar. Crinum, Gilliesia. Haem. Anigozanthos, Haemodorum. Hypox. Hypoxis. Irid. Isophysis, Moraea, Patersonia. Lili. Aloe, Aphyllanthes, Asparagus, Dianella. Rusc. Ruscus. Smil. Smilax. Trill. Trillium.

63. Clifford, H.T. (1977) Quantitative studies of inter-relationships amongst the Liliatae. Pl. Syst. Evol., Suppl. 1, 77-95. Use of computer techniques for generating classifications. 88 families classified, using 51 attributes.

64. Clifford, H.T. \& Williams, W.T. (1980) Interrelationships amongst the Liliatae: a graph theory approach. Aust. J. Bot. 28, 261-8. Classification.

65. Cremer, M.C., Beijer, J.J. \& Munk, W.J. de (1974) Developmental stages of flower formation in tulips, narcissi, irises, hyacinths, and lilies. Meded. 
Landbouwhogesch. Wageningen 74 (15) 1-16. Mainly morphological. Amar. Narcissus. Irid. Iris. Lili. Hyacinthus, Lilium, Tulipa.

66. Croizat, L. (1972) En torno al concepto de hoja. Ensayo de botánica analitica y sintetica. Bol. Acad. Ci. Fis. Mat. Nat., Venez, 32, 29-207. [English summary] [Bull. Signal, CNRS 370, 35 (1974) No. 4496.] Concept of leaf. Lili. Asparagus in particular.

67. Cronquist, A. (1968) The evolution and classification of flowering plants. Houghton Mifflin Co.: Boston. 396 pp.

68. Cutler, D.F. (1972) Leaf anatomy of certain Aloe and Gasteria species and their hybrids. pp.103-22 in: Research trends in plant anatomy (eds. Ghouse, A.K.M. \& Yunus, M.) Tata McGraw-Hill Publ. Co., Bombay \& New Dehli. Lili. SEM.

69. Cutler, D.F. (1978) The significance of variability in epidermal cell wall patterns of Haworthia reinwardtii var. chalumnensis (Liliaceae). Revta Bras. Bot. 1, 25-34. SEM.

70. Cutler, D.F. (1979) Leaf surface studies in Aloe and Haworthia species (Liliaceae): taxonomic implications. Trop. Subtrop. Pflwelt, No. 28, 1-29. Aloe 11 spp., Haworthia 16 spp. SEM.

71. Cutler, D.F. \& Brandham, P.E. (1977) Experimental evidence for the genetic control of leaf surface characters in hybrid Aloineae (Liliaceae). Kew Bull. 32, 23-32. Aloe, Gasteria, Haworthia. Hybrids and parents. SEM.

72. Cutler, D.F., Brandham, P.E., Carter, S. \& Harris, S.J. (1980). Morhpological, anatomical, cytological and biochemical aspects of evolution in East African shrubby species of Aloe L. (Liliaceae). Bot. J. Linn. Soc. 80, 293-317. SEM leaf surface.

73. Cyunel, E. (1972) An anatomical analysis of Paris quadrifolia L. Acta Biol. Cracov., Ser. Bot. 15, 205-8. Trill. Vegetative anatomy.

74. Cyunel, E. (1973) Pharmacobotanical investigations on species of Veratrum L. in Poland. I. Anatomical analysis of Veratrum nigrum L. Acta Biol. Cracov., Ser. Bot. 16, 23-8. Lili. Vegetative and floral anatomy.

75. Dahlgren, R. (1975) A system of classification of the angiosperms to be used to demonstrate the distribution of characters. Bot. Notiser 128, 119-47.

76. Dahlgren, R. (1977) A commentary on a diagrammatic presentation of the angiosperms in relation to the distribution of character states. $P l$. Syst. Evol., Suppl. 1, 253-83. Characters include: presence of vessels, epigyny, endosperm, raphides, silica.

77. Dahlgren, R.M.T. (1980) A revised system of classification of the angiosperms. Bot. J. Linn. Soc. 80, 91-124. A revision of his 1975 work.

78. Dashek, W.V., Thomas, H.R. \& Rosen, W.G. (1971) Secretory cells of lily pistils. II. Electron microscope cytochemistry of canal cells. Amer. J. Bot. 58, 909-20. Lili. Lilium. TEM.

79. Daumann, E. (1970) Das Blütennektarium der Monocotyledonen unter besonderer Berücksichtigung seiner systematischen und phylogenetischen Bedeutung. Feddes Repert. 80, 463-590. Includes All., Amar., Haem., Hypox., Irid., Lili., Rusc., Smil., Trill. Many genera.

80. Deloire, A. (1980) Les racines tractrices de l'Allium polyanthum Roem. et Schult.: une étude morphologique, anatomique et histoenzymologique. Rev. Cytol. Biol. Vég., Bot. 3, 383-90. All.

81. DeMason, D.A. (1979) Histochemistry of the primary thickening meristem in the vegetative stem of Allium cepa L. Amer. J. Bot. 66, 347-50. All.

82. DeMason, D.A. (1979) Function and development of the primary thickening meristem in the monoctyledon, Allium cepa L. Bot. Gaz. 140, 51-66. All.

83. DeMason, D.A. (1980) Localization of cell division activity in the primary thickening meristem in Allium cepa L. Amer. J. Bot. 67, 393-9. All.

84. De Vos, M.P. (1970) Bydrae tot die morfologie en anatomie van Romulea: I. Die knol. Jl. S. Afr. Bot. 36, 215-28. [English summary] Irid. Corm anatomy. c. $50 \mathrm{~S}$. African spp. 
85. De Vos, M.P. (1970) Bydrae tot die morfologie en anatomie van Romulea: II. Die blare. Jl. S. Afr. Bot. 36, 271-86. [English summary] Irid. Leaf anatomy. c. $50 \mathrm{~S}$. African spp.

86. De Vos, M.P. (1971) Bydrae tot die morfologie en anatomie van Romulea: III. Die bloeiwyse en blom. $J l$. S. Afr. Bot. 37, 57-70. [English summary] Irid. Floral anatomy.

87. De Vos, M.P. (1972) The genus Romulea in South Africa. Jl. S. Afr. Bot., Suppl. vol.9, 1-307. Irid. Leaf anatomy, pp.11-14. Summary of work more fully dealt with in De Vos 1970.

88. De Vos, M.P. (1974) Duthiella, 'n nuwe genus van die Iridaceae. Jl. S. Afr. Bot. 40, 301-9. Irid. Corm morphology, leaf T.S., seed anatomy.

89. De Vos, M.P. (1974) De suid-afrikaanse genus Syringodea. Jl. S. Afr. Bot. 40, 201-54. [English summary] Irid. Taxonomic monograph, including corm, leaf, testa and pericarp anatomy.

90. De Vos, M.P. (1976) Die Suid-Afrikaanse spesies van Homoglossum. Jl. S. Afr. Bot. 42, 301-59. [English summary] Irid. Taxonomy. Also leaf and corm anatomy.

91. De Vos, M.P. (1979) The African genus Ferraria. Jl. S. Afr. Bot. 45, 295-375. Irid. Taxonomy; corm morphology and leaf anatomy.

92. Di Fulvio, T.E. (1973) Sobre el gineceo de Allium y Nothoscordum. Kurtziana 7, 241-53. [English summary] All. Floral morphology.

93. Di Fulvio, T.E. (1973) La semilla y la plántula de Nothoscordum arenarium (Liliaceae). Kurtziana 7, 267-8. All. Morphology only.

94. Doncheva, A.D. (1973) [Studies on organogenesis in Tulipa gesneriana L.] Gradinarska Lozarska Nauk 10 (2), 129-35. [Bulg.] [Bibl. Agric. 37 (1973) No. 096395] Lili.

95. Doyle, J.A. (1973) Monocotyledons: their evolution and comparative biology. V. Fossil evidence on early evolution of the monocotyledons. $Q$. Rev. Biol. 48, 399-413. Defines basic monocot. leaf characters.

96. Dutt, B.S.M. \& Rao, P.S.P. (1975) Embryo sac development in Scilla peruviana L. Curr. Sci. 44, 91-2. [Bibl. Agric. 39 (1975) No. 161983] Lili.

97. Dvorakovskaya, V.M. (1971) [Development of embryo and germination of seeds of Fritillaria ruthenica.] In: Morfologiya Tsvetkovykh Rastenii 170-80. [Russian] [Bibl. Agric. 36 (1972) No. 039614.] Lili.

98. Dvorakovskaya, V.M. (1973) [Rhythm of development of shoots and juvenile plants of some species of the genus Fritillaria.] nauch. Dokl. vyssh. Shk., biol. Nauki 16 (8), 58-63. [Russian] [Biol. Abstr. 58 (1974) No. 817.] Lili. Includes bulb structure.

99. Eie, S. (1972) Floral anatomy in Tofieldia pusilla (Michx.) Pers. with special reference to the gynoecium. Norwegian J. Bot. 19, 31-6.

100. Ekberg, L. (1972) Studies in the genus Allium IV. Vegetative reproduction in Allium unifolium and some other American species. Bot. Notiser 125, 82-6. All. Bulb morphology. $4 \mathrm{spp}$.

101. Ekberg, L. (1972) Studies in the genus Allium V. Bulb structure in the Section Anguinum. Bot. Notiser 125, 87-92. All. 2 spp.

102. Ekberg, L. (1972) Studies in the genus Allium VI. Bulb structure in the subgenus Melanocrommyum. Bot. Notiser 125, 93-101. All. Also note on leaf anatomy.

103. El-Gazzar, A. \& Badawi, A.A. (1975) The taxonomic position of Asparagus L. Phytologia 29, 472-6. Lili. Includes 'associated stomata' (= contiguous stomata).

104. El-Gazzar, A., Badawi, A.A. \& Hamza, M.k. (1977) The distribution of associated stomata in angiosperms, I. Monocotyledoneae. Publ. Cairo Univ. Herb., Nos. 7-8, 47-55. Includes All., Amar., Lili., Rusc.

105. Erdelska, O. \& Ryczkowski, M. (1972) Osmotic values and anatomic structure of individual parts of Haemanthus katharinae Bak. seed. Biologia ser. A, Bot. 27, 241-8. [Bibl. Agric. 36 (1972) No. 113463.] Amar. 
106. Ervin, E.L. \& Evert, R.F. (1970) Observations on sieve elements in three perennial monocotyledons. Amer. J. Bot. 57, 218-24. Includes Lili. Polygonatum. Smil. Smilax.

107. Ervin, E.L. \& Sikkema, J. (1971) [1972] Ectodesmata of Smilax hispida stems. Phytomorphology 21, 247-50. Smil.

108. Ervin, E.L. \& Syperda, G. (1971) Seasonal effects on soluble sugars and cytological aspects of Polygonatum canaliculatum rhizomes. Bull. Torrey Bot. Cl. 98, 162-7. Lili.

109. Esau, K. \& Gill, R.H. (1973) Correlations in differentiation of protophloem sieve elements of Allium cepa root. J. Ultrastruct. Res. 44, 310-28. All. TEM.

110. Ferri, S. (1974) Morphological and structural investigations on Smilax aspera leaf and storage starches. J. Ultrastruct. Res. 47, 430-32. Smil. SEM and TEM.

111. Fisher, J.B. (1973) The monocotyledons: their evolution and comparative biology. II. Control of growth and development in the monocotyledonsnew areas of experimental research. $Q$. Rev. Biol. 48, 291-8. Includes nature of leaf.

112. Fisher, J.B. \& French, J.C. (1976) The occurrence of intercalary and uninterrupted meristems in the internodes of tropical monocotyledons. Amer. J. Bot. 63, 510-25. Includes Lili. Gloriosa. Smil. Smilax.

113. Fisher, J.B. \& French, J.C. (1978) Internodal meristems of monocotyledons: further studies and a general taxonomic summary. Ann. Bot. 42, 41-50. Includes All. Allium. Amar. Agapanthus, Hippeastrum, Stenomesson. Haem. Anigozanthos. Irid. Iris, Neomarica, Sisyrinchium, Trimezia, Tritonia, Watsonia. Lili. Aloe, Arthropodium, Bulbine, Dianella, Hemerocallis, Ornithogalum.

114. Franck, D.H. (1975) Early histogenesis of the adult leaves of Darlingtonia californica (Sarraceniaceae) and its bearing on the nature of epiascidiate foliar appendages. Amer. J. Bot. 62, 116-32. All. Irid. Interpretation of tubular leaves including comparison with leaves of Iris and Allium.

115. Freire de Carvalho, L. d'A. (1976) Considerações sobre a vascularização foliar de Hypoxis decumbens L.-Hypoxidaceae. Rodriguesia 28, No. 40, 274-81.

116. Furst, G.G. (1970) [Anatomical-histochemical observations of the first-year bulbs of various species of Allium.] Byull. Glavn. Bot. Sada 77, 75-82. [Russian] All.

117. Furst, G.G. (1973) [Structure of the waxy covering of the leaves in various species of Allium.] Byull. Glavn. Bot. Sada 88, 82-7. [Russian] All.

118. Furst, G.G. (1976) [An investigation of the stomatal apparatus of the leaves of various species of Allium in connection with their resistance to downy mildew.] Byull. Glavn. Bot. Sada 99, 81-91. [Russian] All.

119. Furst, G.G. (1976) [Anatomical-histochemical observations on the mesophyll of leaves of Allium species.] Byull. Glavn. Bot. Sada 102, 74-80. [Russian] All.

120. Furst, G.G. (1976) [Anatomical and histochemical properties of onion species resistant and susceptible to downy mildew.] pp.51-63 in: Fiziologiya immuniteta kul'turnikh rastenii. Akad. Nauk SSSR. Izdat. Nauka: Moskva. [Russian] All.

121. Gaff, D.F. \& Churchill, D.M. (1976) Borya nitida Labill. -an Australian species in the Liliaceae with desiccation-tolerant leaves. Aust. J. Bot. 24, 209-24. Lili. Leaf anatomy and physiology.

122. Gaff, D.F., Zee, S.-Y. \& O'Brien, T.P. (1976) The fine structure of dehydrated and reviving leaves of Borya nitida Labill.-a desiccation-tolerant plant. Aust. J. Bot. 24, 225-36. Lili. TEM.

123. Gambarova, R.K. (1972) [Embryological features of Hyacinthus romanus L. on Apsheron Peninsula.] pp.112-20 in: Tsitoembriologicheskie 
Issledovaniya Rastenii Flory Azerbaidzhana. [Russian] [Bibl. Agric. 37 (1973) No. 086774.] Lili.

124. Garbari, F., Greuter, W. \& Miceli, P. (1979) The Allium cupani group: a preliminary taxonomic, caryological and leaf anatomical study. Webbia 34, 459-80. All.

125. Gilford, J. McD. \& Rees, A.R. (1974) The tulip shoot apex. I. Structure and development. Scientia Hort. 2, 1-10. Lili. Tulipa bulb.

126. Gilford, J.McD. \& Rees, A.R. (1974) The tulip shoot apex. II. Growth. Scientia Hort. 2, 11-20. Lili. Tulipa. Growth rates.

127. Gohil, R.N. \& Kaul, R. (1980) [1981] An interesting variation in the development of the female gametophyte of Allium consanguineum. Caryologia 33, 295-7. All.

128. Goldblatt, P. (1971) Cytological and morphological studies in the Southern African Iridaceae. Jl. S. Afr. Bot. 37, 317-460. Classification. 43 genera.

129. Golyshkin, L.V. (1977) [Cytologic studies of microsporogenesis and pollen formation in five species of onion.] Trudy Prikl. Bot., Genet. Selek. 60 (2), 39-81. [Russian; English summary] All.

130. Greller, A.M. \& Matzke, E.B. (1970) [1971] Organogenesis, aestivation, and anthesis in the flower of Lilium tigrinum. Bot. Gaz. 131, 304-11. Lili.

131. Guaglianone, E.R. (1972) Sinopsis de las especies de Ipheion Raf. y Nothoscordum Kunth (Liliáceas) de Entre Rios y regiones vecinas. Darwiniana 17, 159-242. All. Includes leaf anatomy, starch grains.

132. Guédès, M. (1972) Contribution à la morphologie du phyllome. Mem. Mus. natn. Hist. nat., Paris (N.S.) sér. B, 21, 1-179. Includes All. Allium. Lili. Tulipa. Smil. Smilax. Cotyledons, vegetative leaves, stipules (ligules), bracts, floral parts. Morphology, anatomy, homology.

133. Guédès, M. (1980) Architecture de la feuille équitante d'Iris. C.r. Acad. Sci., Paris, D, 290, 131-4. Irid. evidence from study of variegated leaves.

134. Gupta, S.C. \& Nanda, K. (1973) Fibrous endothecium, tapetum, and pollen development in Belamcanda chinensis DC. Bot. Gaz. 134, 125-9. Irid.

135. Gvaladze, G.E. (1979) Asynchronous division in embryo and endosperm in Liliaceae. Proc. Indian natn. Sci. Acad., B, 45, 596-604. All. Allium. Lili. Gagea, Lilium, Muscari, Scilla, Tulipa.

136. Haccius, B. \& Hausner, G. (1972) Frühembryogenese und PolyembryonieProblem in der Gattung Tulipa L. Beitr. Biol. Pfl. 48, 207-28. Lili.

137. Harris, P.J. \& Hartley, R.D. (1980) Phenolic constituents of the cell walls of monocotyledons. Biochem. Syst. Ecol. 8, 153-60. 104 spp. in 52 families, divided into 2 groups on UV fluorescence of cell walls.

138. Heinrich, G. (1975) Uber den Glucose-Metabolismus in Nektarien zweier AloeArten und über den Mechanismus der Pronektar-Sekretion. Protoplasma 85, 351-71. Lili. Floral nectaries TEM.

139. Heinrich, G. (1975) Über die Lokalisation verschiedener Phosphatasen im Nektarium von Aloe. Cytobiologie 11, 247-63. [Bull. Signal., CNRS 370, 37 (1976) No. 1232.] Lili. TEM.

140. Hertogh, A.A. de, Rasmussen, H.P. \& Blakely, N. (1976) Morphological changes and factors influencing shoot apex development of Lilium longiflorum Thunb. during forcing. J. Amer. Soc. Hort. Sci. 101, 463-71. Lili. SEM of apex during change to reproductive stage.

141. Heslop-Harrison, J. \& Heslop-Harrison, Y. (1975) Fine structure of the stigmatic papilla of Crocus. Micron 6, 45-52. Irid. TEM and SEM cuticle and wall of papillae.

142. Hickey, L.J. (1979) [1980] A revised classification of the architecture of dicotyledonous leaves. pp.25-39 in: Anatomy of the dicotyledons. I. (Metcalfe, C.R. \& Chalk, L.) Clarendon Press: Oxford. 2nd edn.

143. Hilliard, O.M. \& Burtt, B.L. (1978) Notes on some plants from southern Africa chiefly from Natal: VII. Notes $R$. Bot. Gard. Edinb. 36, 43-76. Hypox. Rhodohypoxis, Saniella. Leaf anatomy. 
144. Hirsch, A.M. (1977) A developmental study of the phylloclades of Ruscus aculeatus L. Bot. J. Linn. Soc. 74, 355-65. Rusc.

145. Huang, Shiu-Mei \& Sterling, C. (1970) Laticifers in the bulb scales of Allium. Amer. J. Bot. 57, 1000-3. All.

146. Huber, H. (1969) Die Samenmerkmale und Verwandtschaftsverhältnisse der Liliifloren. Mitt. bot. Staatssamm. München 8, 219-538. Numerous genera. All., Amar., Haem., Hypox., Lili., Rusc., Smil., Trill. Discussion of family relationships.

147. Huber, H. (1977) The treatment of the monocotyledons in an evolutionary system of classification. Pl. Syst. Evol., Suppl. 1, 285-98.

148. Inamdar, A.C. \& Mahabale, T.S. (1974) Floral anatomy in some species of the genus Asparagus L. Maharashtra Vidnyan Mandir Patrika 9, 83-90. [Biol. Abstr. 60 (1975) No. 53048.] Lili.

149. Ivanskaya, E.N. (1975) [To the anatomical characteristics of some alpine plants of the central Caucasus.] Byull. Mosk. Obshch. Ispyt. Prir., Otd. Biol. 80 (6) 73-81. [Russian; English summary] Includes Amar. Galanthus. Lili. Fritillaria. Brief notes only; stem and leaf anatomy.

150. Jacobsen, T.D. (1979) Numbers and distributions of vascular bundles in scapes of three alliances of the genus Allium L. (Liliaceae). Amer. J. Bot. 66, 991-2. All.

151. Jamiolkowska, B. \& Zawadzka, Z. (1971) [1972] Rozwój Narcissus peoticus L. [Development of Narcissus poeticus L.] Acta Agrobot., Warsaw, 24, 269-80. [English summary] Amar. Vegetative and reproductive apices.

152. Jernstedt, J.A. (1980) Anthesis and floral senescence in Chlorogalum pomeridianum (Liliaceae). Amer. J. Bot. 67, 824-32. Anatomy. LM, SEM. Ethylene production and senescence.

153. Jernstedt, J.A. (1980) Ultraviolet absorption by flowers of Chlorogalum (Liliaceae). Bull. Torrey Bot. Club 107, 163-71. SEM cuticle of sepals and ovary. Tepal anatomy.

154. Jessop, J.P. (1970) Studies in the bulbous Liliaceae: 1. Scilla, Schizocarphus and Ledebouria. Jl. S. Afr. Bot. 36, 233-66. Brief notes on leaf anatomy, etc. p. 237 .

155. Jessop, J.P. (1972) Studies in the bulbous Liliaceae in South Africa: 2 Drimiopsis and Resnova. Jl. S. Afr. Bot. 38, 151-62. Brief notes on leaf anatomy of Scilla, Ledebouria, Drimiopsis. Suggests Resnova should be included in Drimiopsis.

156. Jessop, J.P. (1976) A revision of Peliosanthes (Liliaceae). Blumea 23, 141-59. Comparison with Ophiopogon: differences in leaf epidermal characters.

157. Jones, D. (1978) Surface morphology of Narcissus flowering stems as revealed by scanning electron microscopy. Micron 9, 95-7. Amar. differences in wax structure according to preparation technique: freeze-dried or criticalpoint-dried.

158. Junker, S. \& Reinhold, L. (1975) A scanning electron microscope survey of the surface of sensitive tendrils. J. Micr. Biol. cell., Fr. 23, 175-80. [Bull. Signal., CNRS 370, 37 (1976) No. 3474.] Includes Smil. Smilax.

159. Kalashnikov, I.D. (1970) [Anatomical characteristics of some species of Galanthus L.] Byull. Glavn. Bot. Sada 77, 41-6. [Russian] Amar. Vegetative anatomy $3 \mathrm{spp}$.

160. Kamble, S.Y. \& Ansari, M.W. (1977). Notes on anatomy of leaves and scapes of some species of the genus Urginea Steinh. Maharashtra Vidnyan Mandir Patrika 12 (2), 80-3. Lili.

161. Kapinos, G.E. (1972) [Embryological survey of Galanthus caspius (Rupr.) A. Qrossh.] pp. 121-30 in: Tsitoembriologicheskie Issledovaniya Rastenii Flory Azerbaidzhana. [Russian] [Bibl. Agric. 37 (1973) No. 086775.] Amar.

162. Kapinos, G.E. (1972) [Cytoembryological study of ancient and rare species of Danae Medik. and Ruscus L. (Liliaceae family).] pp.4-49 in: Tsitoembriologicheskie Issledovaniya Rastenii Flory Azerbaidzhana. [Russian] [Bibl. Agric. 37 (1973 No.086776.] Rusc. 
163. Kaplan, D.R. (1971) [1972] On the value of comparative development in phylogenetic studies-a rejoinder. Phytomorphology 21, 134-40.

164. Kaplan, D.R. (1973) The monocotyledons: their evolution and comparative biology: VII. The problem of leaf morphology and evolution in the monocotyledons. $Q$. Rev. Biol. 48, 437-57. Discussion of phyllode theory, unifacial leaves, etc. Examples include: Lili. Hosta, Ornithogalum.

165. Kaplan, D.R. (1975) Comparative developmental evaluation of the morphology of unifacial leaves in the monocotyledons. Bot. Jb. 95, 1-105. Historical survey and original work; criticism of various theories. Examples include All. Allium. Lili. Hosta, Ornithogalum.

166. Karagyozova, M.D. (1973) Anatomy of leaf blade of Ophiopogon jaburan Lodd. var. variegatus. C.R. Acad. bulg. Sci. 26, 703-5. [Bibl. Agric. 37 (1973) No. 113061.] Lili.

167. Kazakova, A.A. \& Zhestjanikova, L.L. (1971) [Characteristics of anatomical structure of onion stalk.] Trudy Prikl. Bot. Genet. Selek. 45 (1), 246-59. [Russian; very brief English summary.] All. Basal stem of 7 spp. of Allium.

168. Khokhryakov, A.P. (1971) [Some patterns of the evolution of gametophytes and embryos in connection with evolution of the seeds and seedlings of monocotyledons.] Byull. Mosk. Obshch. Ispyt. Prir., Biol. 76 (4), 62-73. [Russian; English summary.] Palms and arboreal Liliales regarded as most primitive monocotyledons.

169. Khokhryakov, A.P. (1975) [Somatic evolution of the monocotyledons.] Nauka: Moscow. [Russian] [Bull. Signal., CNRS 37037 (1976) No. 916.] Origin, evolution and systematics of monocotyledons. Evolution and classification of Liliaceae.

170. Kiselyova, T.M. (1977) [Structure of leaves and plastid apparatus in some herbaceous species of spruce forest.] Bot. Zh. SSSR 62, 1011-15. [Russian.] Includes Lili. Majanthemum.

171. Kluge, M., Knapp, I., Kramer, D., Schwerdtner, I. \& Ritter, H. (1979) Crassulacean acid metabolism (CAM) in leaves of Aloe arborescens Mill. Comparative studies of the carbon metabolism of chlorenchym and central hydrenchym. Planta 145, 357-63. Lili. TEM.

172. Kluge, M. \& Ting, I.P. (1978) Crassulacean acid metabolism. Analysis of an ecological adaptation. Springer-Verlag: Berlin, Heidelberg, New York. 209 pp. Distribution of CAM plants; morphology and anatomy; physiology; ecology and economic use. Chloroplast TEM. Includes Lili.

173. Kojić, M. \& Gajić, M. (1973) [Comparative investigations of some ecophysiological and anatomical characteristics of some Mediterranean and sub-Mediterranean species.] Glasnik Sumarskog Fag., Beograd, No.44, 99-116. [Serbo-Croat; English summary.] [For. Abstr. 35 (1974) No. 5905.] Includes Rusc. Ruscus leaf.

174. Komar, G.A. (1973) [Arilloids of some Scilla species.] Bot. Zh. SSSR 58, 1503-8. [Russian.] Lili. seed anatomy.

175. Komar, G.A. (1974) [The arillus in the representatives of the genus Chionodoxa.] Bot. Zh. SSSR 59, 1617-22. [Russian.] Lili. Seed anatomy.

176. Komar, G.A. (1976) [The ultrastructure of seed appendages (elaiosomes) in Scilla sibirica, Scilla mischtschenkoana and Chionodoxa gigantea (Liliaceae).] Bot. Zh. SSSR 61, 332-41. [Russian; English summary.] Lili. TEM.

177. Komar, G.A. (1978) [Arills and arill-like formations in some Liliales.] Bot. $Z$ h. SSSR 63, 937-55. [Russian; English summary.] Includes All. Allium. Amar. Galanthus, Leucojum. Irid. Iris. Lili. Aloe, Asphodeline, Asphodelus, Colchicum, Erythronium, Gagea, Iphigenia, Lloydia. Trill. Scoliopus, Trillium.

178. Kothari, I.L. (1979) Morphohistogenic and anatomical studies in garlic: phloem. Proc. Indian Acad. Sci., B, 88, 219-24. All. Allium. Vegetative parts.

179. Kothari, I.L., Patel, J.D. \& Shah, J.J. (1980) Morphohistogenic and anatomical studies in Allium sativum L. I. Root apical meristem. Flora 169, 230-7. All.

180. Kothari, I.L., Patel, J.D. \& Shah, J.J. (1980) Morphohistogenic and anatomical 
studies in Allium sativum L. II. Nuclear autolysis in phloem and laticifer. Flora 169, 238-44. All. Vegetative parts.

181. Kothari, I.L. \& Shah, J.J. (1974) Histogenesis of seed stalk and inflorescence in garlic. Phytomorphology 24, 42-8. All. Allium.

182. Kothari, I.L. \& Shah, J.J. (1974) Structure and organization of shoot apex of Allium sativum L. Israel J. Bot. 23, 216-22. All.

183. Kotlyar, V.Z. (1974) [On the role of the crystal system with rotational formations of globular form in cells of conducting pathways in Aspidistra elatior Blume leaves.] Ukrain. bot. Zh. 31, 373-5. [Ukrainian; brief English summary.] Lili.

184. Koul, A.K., Wafai, B.A. \& Wakhlu, A.K. (1976) [1977] Studies on the genus Gagea. III. Sporogenesis, early embryogeny and endosperm development in hexaploid Gagea stipitata. Phytomorphology 26, 255-63. Lili.

185. Krahulec, F. (1977) Poznámky k určováni československých česneku (Allium L.) v nekvetoucim stavu. Zprav. česk. bot. Spol. 12, 145-59. All. Leaf epidermis.

186. Krahulec, F. (1980) Epidermal characters of Allium species autochthonous in Czechoslovakia: their pattern, taxonomic and ecological relationships. Preslia 52, 299-309. All. Mostly LM, some SEM. $15 \mathrm{spp}$.

187. Kristen, U. (1973) Elektronenmikroskopische Untersuchungen an den Epidermiszellen der Schalenblattoberseite von Allium cepa. Mitt. Staatsinst. Bot. Hamburg 14, 5-17. All. TEM.

188. Krulik, G.A. (1980) Light transmission in window-leaved plants. Can. J. Bot. 58, 1591-1600. SEM 'window' tissues from leaves. Includes Lili. Haworthia.

189. Krusheva, R. \& Belcheva, R. (1973-5) [1977] [Megagametogenesis in Lilium regale Wils.] Sofii Univ. Biol. Fak. God. 68 (2), 81-8. [Bulgarian; English summary.] [Biol. Abstr. 66 (1978) No. 9611.] Lili.

190. Krusheva, R.M. \& Belcheva, R.G. (1976) [Details of macrogametogenesis in Lilium regale Wils.] Citol. Genet., SSSR 10 (1), 45-8. [Russian; English summary] [Bull. Signal., CNRS 370, 37 (1976) No. 11391.] Lili.

191. Kujat, R. \& Rafinski, J.N. (1978) Seed coat structure of Crocus vernus agg. (Iridaceae). Pl. Syst. Evol. 129, 255-60. SEM.

192. Lakshmanan, K.K. \& Philip, V.J. (1971) A contribution to the embryology of Iridaceae. Proc. Indian Acad. Sci., B, 73, 110-16. [Biol. Abstr. 52 (1971) No. 120066.]

193. Lam, T.H., Ho, Y.B. \& Chen, S. (1980) Observations on ultraviolet-fluorescent trichomes on the tepals of Narcissus flowers. Pl. Sci. Lett. 18, 115-20. Amar. Trichomes possibly function as guides to insects.

194. Lazarte, J.E. \& Palser, B.F. (1979) Morphology, vascular anatomy and embryology of pistillate and staminate flowers of Asparagus officinalis. Amer. J. Bot. 66, 753-64. Lili.

195. Lemattre, P. (1974) Morphologie, anatomie et particularités de la croissance du rhizome du Gloriosa rotschildiana O'Brien. C.R. Acad. Sci., Paris, D, 278, 277-80. [Bull. Signal., CNRS 370, 35 (1974) No. 6240.] Lili.

196. Lenz, L.W. (1976) The nature of the floral appendages in four species of Dichelostemma (Liliaceae). Aliso 8, 383-9.

197. Lersten, N.R. \& Curtis, J.D. (1977) Anatomy and distribution of secretory glands and other emergences in Tofieldia (Liliaceae). Ann. Bot. 41, 879-82. On scapes.

198. Levin, D.A. \& Kerster, H.W. (1978) Rings and age of Liatris. Amer. Nat. 112, 1120-22. Lili. Ecological differences in ring production in corms.

199. Longevialle, M. (1973) Compléments d'informations apportés par l'étude des surfaces en embryogénie. Application à l'étude du développement embryonnaire chez Asparagus officinalis L. Mem. Soc. Bot. Fr. 1973, 367-82. Lili.

200. Lordkipanidze, M.K. (1972) [Study of the assimilatory apparatus of Asparagus 
verticillatus.] Soobshch. Akad. Nauk Gruz. SSR 65, 133-6. [Georgian; English summary.] [Bull. Signal., CNRS 370, 33 (1972) No. 11614.] Lili. Variation with ecological conditions.

201. Lu, C.-Y. \& Chiang, S.-H.T. (1976) Lateral thickening in the stem of Agave rigida Mill. and Aloe vera L. Taiwania 21, 204-19. Lili.

202. Lubbinge, J. (1971) 'n Studie van die anatomiese bou van twee stingels en vier bloei-asse van die genus Aloe. Aloe 9 (4), 13-28. [English summary 44-5.] Lili. Stem and peduncle anatomy.

203. Lunjova, L.S. (1977) [The structure and biology of irises (Iridaceae) vegetative buds.] Bot. Zh. SSSR 62, 563-8. [Russian] Irid.

204. Lužny, J., Vaško, S., \& Wolf, M. (1978) Application of the epispermoscopic analysis for the identification of species and cultivars of the Allium genus. Biul. Warz. Bull. Veg. Crops Res. Work, No. 22, 15-18. All. seed surface films: LM.

205. Macfarlane, T.D. (1980) A revision of Wurmbea (Liliaceae) in Australia. Brunonia 3, 145-208. Also Anguillaria. Leaf \& stem anatomy.

206. Macmillan, B.H. (1972) [1973] Biological flora of New Zealand. 7. Ripogonum scandens J.R. \& G. Forst. (Smilacaceae). Supplejack, Kareao. N.Z. Jl. Bot. 10, 641-72. Anatomy of stem, leaf, root briefly described. Embryology, seed germination and seedling growth, etc.

207. McNaughton, J.E. \& Robertson, B.L. (1974) Megasporogenesis and megagametogenesis in Aloe africana Mill. Jl. S. Afr. Bot. 40, 75-9. Lili.

208. Mahabale, T.S. \& Inamdar, A.C. (1975) Morphology and embryology of Asparagus virgatus Baker. Proc. Indian Acad. Sci. B, 81, 162-9. Lili. Also seed and fruit anatomy.

209. Mahabale, T.S. \& Inamdar, A.C. (1975) Embryology of Asparagus gonoclados Baker. pp.188-94 in: Form, structure and function in plants (eds. Ram, H.Y.M., Shah, J.J. \& Shah, C.K.) Sarita Prakashan: Meerut, India. Lili.

210. Mahran, G.H., Hilal, S.H., Shabana, M.M., Ahmed, M.S. \& Hanna, S. (1975) [1977] Micromorphological study of roots, rhizomes and flowers of Aloe vera L. Bull. Fac. Pharm. Cairo Univ. 14 (2), 1-14. Lili.

211. Malik, C.P. \& Vermani, S. (1975) Physiology of sexual reproduction. I. A histochemical study of the embryo sac development in Zephyranthes rosea and Lagenaria vulgaris. Acta Histochem. 53, 244-80. [Bibl. Agic. 40 (1976) No. 004850.] Amar.

212. Marciniak, K. (1975) Cytochemical investigations of the megasporocyte and embryo sac in Lilium regale at various stages of development. Acta Soc. bot. pol. 44, 335-47. Lili.

213. Mathe, A., Mathe, I. \& Kaposi, P. (1978) Angaben zur Frage der geographischen Rassen und ontogenetischen Entwicklung von Convallaria majalis L. Herba hung. 17 (2), 7-17. [Bull. Signal., CNRS 370, 40 (1979) No. 7916.] Lili.

214. Mbaya, N. (1976) Recherches sur les feuilles unifaciales chez les monocotylédones. Thèse: Dijon. 82 pp. [Bull. Signal., CNRS 370, 38 (1977) No. 6340.] Includes All. Allium. Irid. Iris. Developmental anatomy.

215. Meeuse, A.D.J. (1975) Aspects of the evolution of the monocotyledons. Acta bot. neerl. 24, 421-36. Surveys recent literature on floral morpology, secondary growth, pollen, fossils, etc. and puts forward suggestion that monocotyledons and dicotyledons both originated from pre-angiosperms.

216. Melikyan, A.P. \& Avakyan, K.G. (1975) [Comparative anatomical and palynological study of Armenian specimens of the genus Fritillaria L.] Biol. Zh. Armen. 28 (11), 61-7. [Russian] [Bull. Signal., CNRS 370, 37 (1976) No. 7065.] Lili.

217. Menezes, N.L. de (1980) Evolution in Velloziaceae, with special reference to androecial characters. pp.117-38 in: Petaloid monocotyledons (eds. Brickell, C.D., Cutler, D.F. \& Gregory, M.) Academic Press: London. Discusses relations with Amar., Hypox. 
218. Mentkovskaya, E.A. (1980) [Female gametophyte in certain representatives of the Lilium (Tourn.) L. genus.] Ukrain. Bot. Zh. 37 (3), 44-7. [Ukrainian; English summary.] Lili.

218a. Mérida, T., Schönherr, J. \& Schmidt, H.W. (1981) Fine structure of plant cuticles in relation to water permeability: the fine structure of the cuticle of Clivia miniata Reg. leaves. Planta 152, 259-67. Amar. TEM.

219. Milyaeva, E.L. \& Azizbekova, N. Sh. (1978) [Cytophysiological changes in the course of ontogenesis of saffron stem apices.] Fiziol. Rast. 25, 288-95. [Russian; English summary] [Biol. Abstr. 66 (1978) No. 73415.] Irid. Crocus.

220. Mirkamilov, M.A. (1975) [The structure of ovules of species of the genus Allium L. (Section Molium Don.)] Uzbek Biol. Zh. 19 (1) 75-6. [Russian] All.

221. Mitroiu-Radulescu, N. \& Moroşanu, E. (1974) Donnés embryologiques sur certaines variétés de Freesia. Lucr. Grăd. Bot. Bucuresti (1974) 133-43. Irid.

222. Mordak, H.V. (1970) [Squills indigenous to the Soviet Union. I. The morpholoanatomical characters and their taxonomic value.] Bot. Zh. SSSR 55, 1247-60. [Russian; English summary.] Lili. Scilla 17 spp.

223. Müller-Doblies, D. (1971) [1972] Galanthus ist doch sympodial gebaut. Ber. dt. bot. Ges. 84, 665-82. Amar. Bulb morphology. Also mentioned: Crinum, Hymenocallis, Leucojum.

224. Müller-Doblies, D. (1977) Uber den geometrischen Zusammenhang der monochasialen Verzweigungen am Beispiel einiger Liliifloren. Ber. Dt. Bot. Ges. 90, 351-62. Inflorescence morphology. Amar. Brunsvigia, Crinum. Lili. Scilla.

225. Müller-Doblies, D. \& Müller-Doblies, U. (1978) Zum Bauplan von Ungernia, der einzigen endemischen Amaryllidaceen-Gattung Zentralasiens. Bot. Jb. 99, 249-63. Amar. morphology of bulb, leaves etc.

226. Müller-Doblies, D. \& Müller-Doblies, U. (1978) Studies on tribal systematics of Amaryllidoideae. 1. The systematic position of Lapiedra Lag. Lagascalia 8, 13-23. Bulb and floral morphology. Genus Vagaria restored. Hannonia transferred to Pancratieae, so is Lapiedra.

227. Napp-Zinn, K. (1973; 1974) Anatomie des Blattes. II Blattanatomie der Angiospermen. A. Entwicklungsgeschichtliche und topographische Anatomie des Angiospermenblattes. 2 vols. Gebrüder Borntraeger: Berlin \& Suttgart. 1424 pp. Development; growth; dorsiventrality, bifacial and unifacial leaves; leaf tissues. Lamina, petiole, ligule, stipules, leaf base, pulvinus, abscission zone, cotyledons; developmental anatomy, cataphylls, juvenile leaves, bracts, involucral bracts, perennial leaves and growth; bifacial and unifacial structure, isolateral leaves, ascidia. Summary of references by families.

228. Naumova, T.N. (1978) Peculiarity of macrogametogenesis and post-fertilization development of Trillium camschatcense Ker-Gawl. Bull. Soc. Bot. Fr. 125, Act. Bot. 1/2, 183-6. Trill.

229. Naumova, T.N. \& Yakovlev, M.S. (1975) [Macrogametogenesis of Trillium camschatcense Ker-Gawl.] Bot. Zh. SSSR 60, 342-50. [Russian; English summary.] Trill.

230. Naumova, T.N. \& Yakovlev, M.S. (1975) [Development of embryonic structures in Trillium camschatcense Ker-Gawl. after pollination.] Bot. Zh. SSSR 60, 627-35. [Russian; English summary.] Trill.

231. Nemchenko, E.P. \& Novikov, V.S. (1978) [Anatomical structure of the leaves of some species of Lilium L.] Nauch. Dokl. vyssh. Shk., biol. Nauki (1) 90-7 [Russian] Lili. 15 spp.

232. Nemchenko, E.P. \& Novikov, V.S. (1979) [Anatomical structure of leaves of some Lilium L. species. II.] Nauch. Dokl. vyssh. Shk., biol. Nauki (6) 53-8. [Russian] [Bibl. Agric. 45 (1981) No. 026630.] Lili.

233. Newcomb, W. (1978) The development of cells in the coenocytic endosperm of the African blood lily Haemanthus katherinae. Can. J. Bot. 56, 483-501. Lili. TEM. 
234. Newton, L.E. (1972) Taxonomic use of the cuticular surface features in the genus Aloe (Liliaceae). Bot. J. Linn. Soc. 65, 335-9. SEM leaf.

235. Newton, L. (1976) The taxonomic status of Aloe keayi Reynolds. Natn. Cactus Succ. J. 31, 49-53. Lili. SEM leaf of 3 taxa.

236. Newton, L. (1977) in Aloe cultivar in Ghana. Natn. Cactus Succ. J. 32, 6-7. Lili. SEM leaf.

237. Newton, L.E. \& Lavranos, J.J. (1979) Notes on Aloe fleurentinorum. Natn. Cactus Succ. J. 34, 87-8. Lili. SEM leaf of 2 spp.

238. Niehaus, T.F. (1971) A biosystematic study of the genus Brodiaea (Amaryllidaceae). Univ. Calif. Publ. Bot. 60, 1-66. All. General morphology, leaf and floral anatomy.

239. Niehaus, T.F. (1980) The Brodiaea complex. Genera Brodiaea, Triteleia, Dichelostemma; family Amaryllidaceae. Four Seasons 6 (1), 11-21. All. Includes some anatomical characters of leaf and flower.

240. Novák, F.J. (1972) Tapetal development in the anthers of Allium sativum L. and Allium longicuspis Regel. Experientia 28, 1380-1. All.

241. Obermeyer, A.A. (1978) Ornithogalum: a revision of the southern African species. Bothalia 12, 323-76. Lili. Some SEM photos of seeds.

242. Obermeyer, A.A. (1980) The genus Sypharissa (Liliaceae). Bothalia 13, 111-14. SEM photos of seeds of $3 \mathrm{spp}$.

243. Ornduff, R. \& Dulberger, R. (1978) Floral enantiomorphy and the reproductive system of Wachendorfia paniculata (Haemodoraceae). New Phytol. 80, 427-34.

244. Oryol, L.I. \& Golyshkin, L.V. (1975) [Characteristic features of microsporogenesis and the development of pollen grains in Allium porrum L.] Trudy Prikl. Bot. Genet. Selek. 55 (2) 29-40. [Russian; English summary.] All.

245. Pahuja, A.N. \& Kumar, V. (1970) [1971] Embryo sac development, cytology and systematic position of Clintonia. Phytomorphology 20, 97-102. Lili.

246. Panchaksharappa, M.G. \& Syamasundar, J. (1975) A cytochemical study of ovule development in Dipcadi montanum Dalz. Cytologia 40, 141-9. Lili.

247. Pande, P.C (1979) Vessel specialization in Iridaceae. Acta bot. indica 7, 162-4. Belamcanda, Freesia, Gladiolus, Iris, Ixia, Moraea, Sisyrinchium, Sparaxis, Tritonia. Vessels only in roots.

248. Pande, P.C. (1980) Foliar epidermis and development of stomata in Iridaceae. Acta bot. indica 8, 256-9. Genera as in ref. 247, plus Acidanthera and Crocus.

249. Pande, P.C. \& Singh, V. (1979) [1980] Floral morphology of Iridaceae. Phytomorphology 29, 122-31. Vascular system: Sisyrinchium, Belamcanda, Iris, Moraea, Ixia, Freesia, Tritonia, Sparaxis, Acidanthera, Gladiolus.

250. Panova, D., Ganchev, G., Nikolov, S. \& Stancheva, P. (1977) [Morphologie et anatomie du système radiculaire et des racines d'Asparagus acutifolius L.] Farmatsiya SSSR 27 (3) 7-15. [Bulgarian; English summary.] [Bull. Signal., CNRS 370, 39 (1978) No. 6938.] Lili.

251. Panova, D. \& Zong, N. (1975) [Analyse morphologique et anatomique des racines et rhizomes d'Asparagus tenuifolius Lam.] Farmacija, Bul. 25 (4) 27-34. [Bulgarian; English summary.] [Bull. Signal., CNRS 370, 37 (1976) No. 5942.] Lili.

252. Parkhurst, D.F. (1978) The adaptive significance of stomatal occurrence on one or both surfaces of leaves. $J$. Ecol. $66,367-83$. Leaves with stomata on both surfaces more frequent than leaves with stomata only on lower surface in xeric conditions. Mathematical model. Examples include Lili.

253. Pechenitsyn, V.P. (1972) [The double fertilization in species of Tulipa with Fritillaria-type embryo sac.] Bot. Zh. SSSR 57, 465-9. [Russian; English summary.] Lili.

254. Peterson, C.A., Peterson, R.L. \& Robards, A.W. (1978) A correlated histochemical and ultrastructural study of the epidermis and hypodermis of onion roots. Protoplasma 96, 1-21. All. Allium. TEM and fluorescence. 
Suberin lamella round each hypodermal cell.

255. Qualo, R. (1976) Spaltöffnungstypen bei Haworthien und ihre Bedeutung für die Systematik. Arbeit zum Realschullehrerexamen, Bot. Inst. Univ. Kiel [unpublished.] [Seen in:Straka, H. 1980 Kakt. and. Sukk. 31, p.150.] Lili. 27 spp. from 15 sections examined. Stomatal type too uniform to be useful for systematics.

256. Raghavendra, A.S. \& Das, V.S.R. (1978) The occurrence of $\mathrm{C}_{4}$-photosynthesis: a supplementary list of $C_{4}$ plants, reported during late $1974-$ mid-1977. Photosynthetica, Prague 12, 200-8. [Biol. Abstr. 67 (1979) No. 50559.] Includes Lili.

257. Rajan, S.S. \& Kumar, C.R. (1977) Origin of lateral roots in Allium cepa L. New Bot. 4, 109-11. All.

258. Rao, P.R.M. \& Kaur, A. (1979) Embryology and systematic position of Ophiopogon intermedius. Proc. Indian Natn. Sci. Acad., B, 45, 175-87. Also seed and pericarp anatomy. Suggests genus should be in Liliaceae, not Haemodoraceae.

259. Rao, P.R.M. \& Kaur, A. (1979) [1980] Sporogenesis and gametophytes of Polygonatum cirrhifolium. Phytomorphology 29, 93-7. Lili.

260. Rao, T.A. \& Das, G.C. (1971) [1974] A contribution to the ecological anatomy of maritime strand plants of India. Bull. Bot. Surv. India 13, 319-27. Lili. Asparagus vegetative anatomy.

261. Ravololomaniraka, D. (1972) Contribution à l'étude de quelques feuilles de monocotylédones. Bull. Mus. natn. Hist. nat., Paris sér. 3, No.46, Bot. 2, 29-69. Includes All. Allium. Haem. Conostylis. Irid. Crocus, Gladiolus, Iris. Lili. Dianella, Hyacinthus. Developmental anatomy.

262. Reyneke, W.F. (1973) [Anatomie du genre Eucomis l'Hérit. I. Anatomie de la feuille.] Tydskr. Natuurwet. 13, 134-41. [Afrikaans; English summary.] [Bull. Signal., CNRS 370, 36 (1975) No. 294.] Lili.

263. Reyneke, W.F. (1974) [Anatomie du genre Eucomis l'Hérit. II. Anatomie du pédoncule.] Tydskr. Natuurwet. 14, 64-69. [Afrikaans; English summary.] [Bull. Signal., CNRS 370, 36 (1975) No. 10877.] Lili.

264. Reyneke, W.F. \& Van der Schijff, H.P. (1972) [1973] Primary thickening in the stem of Eucomis pallidiflora Baker. Ber. dt. bot. Ges. 85, 631-41. Lili. Stem of perennial bulb.

265. Reyneke, W.F. \& Van der Schijff, H.P. (1974) The anatomy of contractile roots in Eucomis l'Hérit. Ann. Bot. 38, 977-82. Lili.

266. Reznickova, S.A., Van Aelst, A.C. \& Willemse, M.T.M. (1980) Investigation of exine and orbicule formation in the Lilium anther by scanning electron microscopy. Acta bot. neerl. 29, 157-64. Lili.

267. Rivière, S. (1972) Les activités des méristèmes primaires et les processus de morphogenèse chez une monocotylédone à bulbe: le Lilium candidum L. (Liliacées). Thèse: Univ. Paris. AO CNRS- 7275. 231 pp. 2 vols. [Bull. Signal., CNRS 370, 34 (1973) No. 342.]

268. Rivière, S. (1973) Les activités méristématiques durant l'ontogenèse d'une plantule de monocotylédone à germination hypogée: l'Asparagus officinalis $\mathrm{L}$. (Liliacées). C.R. Acad. Sci., Paris, D, 277, 293-6. [Bull. Signal., CNRS 370,34 (1973) No. 11639.]

269. Roeser, K.R. (1973) Die Staubblätter der Gladiole. Mikrokosmos 62, 268-70. [Bull. Signal., CNRS 370, 35 (1974) No. 1558.] Irid. Gladiolus.

270. Rosen, W.G. \& Thomas, H.R. (1970) Secretory cells of lily pistils. I. Fine structure and function. Amer. J. Bot. 57, 1108-14. Lili. Lilium TEM. Transfer cells.

271. Rotov, R.A. \& Petrova, T.F. (1977) [Characteristics of the development of the embryo sac of Notholirion thomsonianum (Royle) Stapf (Liliaceae).] Byull. Glavn. Bot. Sada 106, 96-100. [Russian] [Bull. Signal., CNRS 370, 39 (1978) No. 11020.]

272. Ruzin, S.E. (1979) Root contraction in Freesia (Iridaceae). Amer. J. Bot. 66, 522-31. LM and SEM. 
273. Sachs, T. (1974) [1975] The developmental origin of stomata pattern in Crinum. Bot. Gaz. 135, 314-18. Amar. Leaf.

274. Saddiqi, S.A. \& Hashmi, S. (1975) The development of female gametophyte in Gagea persica Boiss. Geobios, Jodhpur 2, 87-8. Lili.

275. Sarada, K.S. \& Gracza, P. (1977) [1978] A vöröshagyma fajták leveleinek összehasonlító anatómiai vizsgálata. [Comparative anatomical studies of the leaves of cultivars of onion.] Bot. Közlem. 64, 165-9. [English summary.] All. Allium $3 \mathrm{spp}$.

276. Sargent, C. (1976) Studies on the ultrastructure and development of the plant cuticle. Thesis: Univ. London. 171 pp. Includes Irid. Aristea, Belamcanda, Bobartia, Libertia, Nivenia, Patersonia, Sisyrinchium, Witsenia.

277. Sargent, C. (1976) The occurrence of a secondary cuticle in Libertia elegans (Iridaceae). Ann. Bot. 40, 355-9. TEM, SEM.

278. Sargent, C. (1976) In situ assembly of cuticular wax. Planta 129, 123-6. Irid. Bobartia, Gordonia, Libertia: leaf TEM.

279. Sarma, S.K. \& Terpó, A. (1980) The occurrence of different types of calcium oxalate crystals in Allium cepa L. and Allium fistulosum L. and their importance in taxonomy. Acta Agron. Acad. Sci. Hung. 29 (1-2), 25-37. All. Bulb scales.

280. Sas-Nowosielska, A. \& Wojciechowska, B. (1979) [Diagnostic features of seeds of three Polish Veratrum spp.] Pr. Nauk Uniw. Slask. Katowicach, No. 278, 200-12. (Polish; English summary] [Biol. Abstr. 70 (1980) No. 14523.] Lili. Anatomy.

281. Sattler, R. (1973) Organogenesis of flowers. A photographic text-atlas. Univ. Toronto Press. 207 pp. Includes All. Allium. Lili. Scilla. Rusc. Ruscus.

282. Schaeppi, H. (1975) Über einfache Karpelle. Bot. Job. 96, 410-22. Includes Lili. Tofieldia, Veratrum: morphology.

283. Schill, R. (1973) [1974] Studien zur systematischen Stellung der Gattung Lomatophyllum Willd.; ein Vergleich mit Aloe Tourn. (Liliaceae). Beitr. Biol. Pfl. 49, 273-89. Ovary anatomy, SEM leaf and seed. Suggests Lomatophyllum should be a section of Aloe.

284. Schnepf, E. \& Pross, E. (1976) Differentiation and redifferentiation of a transfer cell: development of septal nectaries of Aloe and Gasteria. Protoplasma 89, 105-15. Lili. TEM.

285. Schulze, W. (1971) Die systematische Stellung der Iridaceen-Gattung Belamcanda Adams. Feddes Repert. 81, 519-26. Leaf and stem anatomy, floral morphology.

286. Sen, S. (1973) Polysomaty and its significance in Liliales. Cytologia 38, 737-51. All. Allium. Lili. Disporum, Drimiopsis, Eremurus, Erythronium, Kniphofia, Lilium, Ornithogalum, Polygonatum, Smilacina, Tulipa, Urginea. Rusc. Ruscus. Root development.

287. Sen, S. (1975) Cytotaxonomy of Liliales. Feddes Repert. 86, 255-305. Evolution of tribes of Liliaceae and of related families discussed.

288. Shah, G.L. \& Gopal, B.V. (1970) Structure and development of stomata on the vegetative and floral organs of some Amaryllidaceae. Ann. Bot. (N.S.) 34, 737-49. Amar. Amaryllis, Crinum, Pancratium, Zephyranthes. Hypox. Curculigo.

289. Shah, J.J. \& Kothari, I.L. (1973) [1974] Histogenesis of garlic cloves. Phytomorphology 23, 162-70. All. Allium bulb.

290. Shorina, N.I. (1975) [Leaf structure in some saffrons in association with the evolution of the genus Crocus L.] Byull. Mosk. Obshch. Ispyt. Prir., Otdel Biol. 80 (4) 117-25. [Russian; English summary.] Irid. 7 spp.

291. Shoub, J. \& Hertogh, A.A. de (1975) Growth and development of the shoot, roots, and central bulblet of Tulipa gesneriana L. cv. Paul Richter during standard forcing. J. Amer. Soc. hort. Sci. 100, 32-7. Lili. LM and SEM.

292. Shpil'oviy, B. Yu. (1977) [Development of female gametophyte in Tulipa subpaestans.] Introd. Aklim. Rosl. Ukr. Akad. Nauk. URSR 10, 106-8. [Ukrainian] [Bibl. Agric. 43 (1979) No. 006138.] Lili. 
293. Shpil'oviy, B. Yu. (1980) [Macrosporogenesis and development of female gametophyte in Gladiolus x hybridus hort.] Ukrain. bot. Zh. 37 (5), 48-54. [Ukrainian; English summary] Irid.

294. Singh, V. (1972) Floral morphology of the Amaryllidaceae. I. Subfamily Amaryllidoideae. Can. J. Bot. 50, 1555-65. Amaryllis, Crinum, Eucharis, Haemanthus, Hippeastrum, Narcissus, Pancratium, Zephyranthes. Anatomy.

295. Sokolov, I.D. (1971) [Les premières phases du développement embryonnaire d'Allium porrum L.] Citol. i Genet., SSSR 5 (6) 555-6. [Russian; English summary] [Bull. Signal., CNRS 370, 33 (1972) No. 5814.] All.

296. Sokolov, I.D. \& Geraskova, T.N. (1974) [Cell formation in the endosperm of Iris pseudacorus L.] Bot. Zh. SSSR 59, 645-9. [Russian; English summary] Irid.

297. Sokolowska-Kulczycka, A. (1973) Development of bisporic embryo sacs in Veratrum lobelianum Bernh. Acta Biol. Cracov., ser. Bot. 16, 85-98. Lili.

298. Sokolowska-Kulczycka, A. (1975) Pathways of development of bisporic embryo sacs. Wiad. Bot. 19, 29-38. [Biol. Abstr. 61 (1976) No. 15220.] Including Lili., Rusc.

299. Sokolowska-Kulczycka, A. (1977) Development of bisporic embryo sacs in Veratrum nigrum L. Acta Biol. Cracov., Ser. Bot. 20, 11-24. Lili.

300. Sokolowska-Kulczycka, A. (1980) Embryological studies of Tofieldia calyculata (L.) Whlb. Acta Biol. Cracov., Ser. Bot. 22, 113-28. Lili.

301. Solntzeva, M.P. (1978) Apomixis and hemigamy as one of its forms. Proc. Indian Natn. Sci. Acad. B, 44, 78-90. Including Amar. Cooperia, Zephyranthes.

302. Solntseva, M.P. \& Vorsobina, L.I. (1979) [The development of the endosperm in Zephyranthes (Amaryllidaceae Jaume St. Hilaire).] Dokl. Akad. Nauk SSSR 245, 509-12. [Russian] [Bull. Signal., CNRS 370, 40 (1979) No. 8834.] Translated in: Dokl. Bot. Sci. Akad. Nauk SSSR 244-6, 31-4 (1979). [Bibl. Agric. 45 (1981) No. 001351.]

303. Speta, F. (1971) Beitrag zur Systematik von Scilla L. subgen. Scilla (inklusive Chionodoxa Boiss.). Ost. Bot. Z. 119, 6-18. Lili. Seed anatomy.

304. Speta, F. (1972) Entwicklungsgeschichte und Karyologie von Elaiosomen an Samen und Früchten. Naturkund. Jb. Linz 9-65. Includes All. Allium. Lili. Hermodactylus, Lachenalia, Puschkinia, Scilla. Trill. Trillium.

305. Sterling, C. (1972) Comparative morphology of the carpel in the Liliaceae: Neodregeae. Bot. J. Linn. Soc. 65, 163-71. Dipidax, Neodregea. Anatomy.

306. Sterling C. (1972) Mechanism of root contraction in Gladiolus. Ann. Bot. 36, 589-98. Irid.

307. Sterling, C. (1972) Les “amylifères" transitoires: une nouvelle catégorie d'organites producteurs d'amidon. C.R. Acad. Sci., Paris, D, 275, 1601-3. Irid. Gladiolus contractile root meristem cells.

308. Sterling, C. (1973) Comparative morphology of the carpel in the Liliaceae: Wurmbaeae. Bot. J. Linn. Soc. 66, 75-82. Anguillaria, Wurmbea. Anatomy.

309. Sterling C. (1973) Comparative morphology of the carpel in the Liliaceae: Colchiceae (Colchicum). Bot. J. Linn. Soc. 66, 213-21. Anatomy.

310. Sterling C. (1973) Comparative morphology of the carpel in the Liliaceae: Colchiceae (Androcymbium). Bot. J. Linn. Soc. 67, 149-56. Anatomy.

311. Sterling, C. (1974) Comparative morphology of the carpel in the Liliaceae: Baeometra, Burchardia and Walleria. Bot. J. Linn. Soc. 68, 115-25. Anatomy.

312. Sterling, C. (1974) Comparative morphology of the carpel in the Liliaceae: Iphigenieae. Bot. J. Linn. Soc. 68, 283-90. Camptorrhiza, Iphigenia, Ornithoglossum. Anatomy.

313. Sterling, C. (1975) Comparative morphology of the carpel in the Liliaceae: Glorioseae. Bot. J. Linn. Soc. 70, 341-9. Gloriosa, Littonia, Sandersonia. Anatomy. 
314. Sterling, C. (1975) Comparative morphology in the carpel of the Liliaceae: tepallary and staminal vascularization in the Wurmbaeoideae. Bot. J. Linn. Soc. 74, 63-9. Androcymbium, Anguillaria, Baeometra, Colchium, Dipidax, Iphigenia, Ornithoglossum, Wurmbea.

315. Sterling, C. (1977) Comparative morphology of the carpel in the Liliaceae: Uvularieae. Bot. J. Linn. Soc. 74, 345-54. Kreysigia, Schelhammera, Uvularia. Anatomy.

316. Sterling, C. (1978) Comparative morphology of the carpel in the Liliaceae: Hewardieae, Petrosavieae, and Tricyrteae. Bot. J. Linn. Soc. 77, 95-106. Hewardia (syn. Isophysis); Petrosavia, Protolirion; Tricyrtis. Anatomy.

317. Sterling, C. (1979) Comparative morphology of the carpel in the Liliaceae: Tofieldieae. Bot. J. Linn. Soc. 79, 321-32. Narthecium, Nietneria, Pleea, Tofieldia. Anatomy.

318. Sterling, C. (1980) Comparative morphology of the carpel in the Liliaceae: Helonieae. Bot. J. Linn. Soc. 80, 341-56. Chamaelirium, Chionographis, Helonias, Heloniopsis, Metanarthecium, Xerophyllum, Ypsilandra. Anatomy.

319. Sterling, C. \& Huang, S.-M. (1972) Notes on the laticifers of Allium, Caloscordum, Nothoscordum, Tristagma and Tulbaghia. Plant Life 28, 43-6. All., Amar.

320. Stewart, R.N. \& Dermen, H. (1979) Ontogeny in monocotyledons as revealed by studies of the developmental anatomy of periclinal chloroplast chimeras. Amer. J. Bot. 66, 47-58. Includes Amar. Ixiolirion. Lili. Aspidistra, Chlorophytum, Ctenanthe, Hemerocallis, Hosta, Liriope: Variegated leaves.

321. Steyn, E. (1973) 'n Embriologiese ondersoek van Romulea rosea Eckl. var. reflexa Beg. 1. Die bou, ontwikkeling en bevrugting van die saadknop. $J l$. S. Afr. Bot. 39, 113-21. [English summary] Irid. Ovule development.

322. Steyn, E. (1973) 'n Embriologiese ondersoek van Romulea rosea Eckl. var. reflexa Beg. 2. Die ontwikkeling van die endosperm, embrio en saadhuid. $J l . S$. Afr. Bot. 39, 235-43. [English summary] Irid.

323. Stirton, C.H. (1981) Petal sculpturing in papilionoid legumes. pp.771-88 in: Advances in legume systematics (eds. Polhill, R.M. \& Raven, P.H.). Royal Botanic Gardens, Kew. SEM.

324. Straka, H. (1980) Über die Spaltöffnungen von Haworthia. Kakt. and. Sukk. $31,149-50$. Lili. Report of a thesis on this topic by Qualo (1976).

325. Strid, A.K. (1974) A taxonomic revision of Bobartia L. (Iridaceae). Opera Bot., Lund, No. 37, 1-45. Leaf and stem anatomy.

326. Stritzke, J.F. \& Peters, E.J. (1972) Anatomy of wild garlic bulbs during and subsequent to after-ripening. Weed Sci. 20, 233-7. All. Allium.

327. Sukhova, G.V. \& Durdiyev, B. (1978) [Leaves anatomical structure for some onions species in the Turkmenistan.] Izv. Akad. Nauk Turkmen. SSR, ser. biol. Nauk (2), 26-9. [Russian; English summary] All. Allium 5 spp.

328. Swamy, B.G.L. \& Krishnamurthy, K.V. (1970) [1971] On the so-called endothelium in the monocotyledons. Phytomorphology 20, 262-9. Includes Lili. Iphigenia.

329. Syamasundar, J. \& Panchaksharappa, M.G. (1976) A histochemical study of some post-fertilization developmental stages in Dipcadi montanum Dalz. Cytologia 41, 123-30. Lili.

330. Syamasundar, J. \& Panchaksharappa, M.G. (1976) A histochemical study of floral nectaries in Dipcadi montanum Dalz, and Allium cepa L. Cytologia 41, 453-57. All., Lili.

331. Tahbaz, F. (1971) [1972] L'Allium "Tarée irani" du groupe ampeloprasum L. cultivé en Iran, région de Téhéran. Bull. Soc. bot. Fr. 118, 753-62. All. Leaf morphology of cultivated taxa.

332. Takhtajan, A.L. (1980) Outline of the classification of flowering plants (Magnoliophyta). Bot. Rev. 46, 226-359. New revised classification, with 
introductory section on criteria used, eg. growth habit, leaves, stomata, nodal anatomy, wood anatomy, inflorescences, floral structure. Families listed, with brief notes on relationships.

333. Talieva, M.N., Furst, G.G., Mishina, G.N. \& Yekhunova, G.A. (1979) [Anatomical-histochemical characteristics of iris varieties differing in resistance to Fusarium.] Byull. Glav. Bot. Sada 113, 67-76. [Russian only] Irid. Especially root anatomy.

334. Tamanyan, K.G. (1975) [Anatomical structure of cladodes of some representatives of the genus Asparagus L.] Biol. Zh. Armen. 28 (5), 69-74. [Russian] [Bull. Signal., CNRS 370, 37 (1976) No. 1377.] Lili.

335. Tamberg, T.G. (1975) [Anatomical structure of leaf in some species of Gladiolus L.] Bot. Zh. SSSR 60, 542-7. [Russian] Irid.

336. Tamberg, T.G. (1975) [Anatomical structure of the stem of Gladiolus.] Byull. Vses. Ord. Lenina Inst. Rast. N.I. Vavilova 54, 69-72. [Russian] Irid. 2 cvs.

337. Tanaka, T., Mizuno, M., Noro, Y. \& Kimura, K. (1978) [Pharmacognostic studies on Mai-men-tung: III On the Mai-men-tung originating from Ophiopogon.] Shoyakugaku Zasshi 32, 136-48. [Japanese; English summary] [Biol. Abstr. 68 (1979) No. 30391.] Lili. Root anatomy.

338. Tanaka, T., Mizuno, M., Noro, Y. \& Kimura, K. (1978) [Pharmacognostical studies of Mai-men-tung: IV. On the Mai-men-tung originated from Liriope.] Shoyakugaku Zasshi 32, 212-21. [Japanese; English summary] [Biol. Abstr. 68 (1979) No. 43121.] Lili. Root tuber anatomy.

339. Taylor, J.J. (1976) A reclassification of Iris species bearing arillate seeds. Proc. biol. Soc. Washington 89, 411-20. [Bull. Signal., CNRS 370, 38 (1977) No. 3146.] Irid.

340. Tellini-Battaglia, G. \& Cristo-Maggini, V. di (1972) Cyto-embryological studies in Scilla madeirensis Menezes. Annali Bot. 31, 125-31. Lili.

341. Terpó, A. \& Sarada, K.S. (1977) [1978] A vöröshagyma (Allium cepa.) fajták kalciumoxalátkristályformáinak taxonómial értéke. [Taxonomica】 significance of the calcium oxalate crystals found in the cultivars of onion (Allium cepa.).] Bot. Közlem. 64, 171-81. [English summary 175-8.] All.

342. Thompson, M.F. (1976) Studies in the Hypoxidaceae. I. Vegetative morphology and anatomy. Bothalia 12, 111-17. Empodium, Pauridia, Spiloxene. Corm and leaf anatomy.

343. Thompson, M.F. (1978) Studies in the Hypoxidaceae. II. Floral morphology and anatomy. Bothalia 12, 429-35. Empodium, Pauridia, Spiloxene.

344. Thompson, M.F. (1979) Studies in the Hypoxidaceae. III. The genus Pauridia. Bothalia 12, 621-5. Taxonomic, with note on leaf anatomy.

345. Thorne, R.F. (1976) A phylogenetic classification of the Angiospermae. pp. 35-106 in: Evolutionary biology 9 (eds. Hecht, M.K., Steere, W.C. \& Wallace B.) Plenum Press.

346. Thorne, R.F. (1977) Some realignments in the Angiospermae. Pl. Syst. Evol., Suppl. 1, 299-319. Reasons for some of the positions of families in his system of classification.

347. Tilton, V.R. (1980) A new type of specialized cell in the gynoecium of Ornithogalum caudatum (Liliaceae) with notes on specialized cells in carpels of other taxa. Ann. Bot. 46, 527-32. Idioblasts.

348. Tilton, V.R. (1980) The nucellar epidermis and micropyle of Ornithogalum caudatum (Liliaceae) with a review of these structures in other taxa. Can. J. Bot. 58, 1872-84. TEM \& SEM.

349. Tilton, V.R. (1980) Hypostase development in Ornithogalum caudatum (Liliaceae) and notes on other types of modifications in the chalaza of angiosperm ovules. Can. J. Bot. 58, 2059-66.

350. Tilton, V.R. (1980) Aberrant ovules in angiosperms: a review of selected examples and new observations on Ornithogalum caudatum (Liliaceae). Proc. Iowa Acad. Sci. 87 (1), 23-8. [Biol. Abstr. 70 (1980) No. 24416.]

351. Tilton, V.R. \& Horner, H.T. (1980) Calcium oxalate raphide crystals and 
crystalliferous idioblasts in the carpels of Ornithogalum caudatum. Ann. Bot. 46, 533-9. Lili. SEM, TEM.

352. Tilton, V.R. \& Horner, H.T. (1980) Stigma, style, and obturator of Ornithogalum caudatum (Liliaceae) and their function in the reproductive process. Amer. J. Bot. 67, 1113-31. SEM, TEM.

353. Tomlinson, P.B. (1974) Development of the stomatal complex as a taxonomic character in the monocotyledons. Taxon 23, 109-28. Includes Amar., Haem., Hypox., Irid., Lili., Rusc., Smil., Trill.

354. Tomlinson, P.B. (1980) Monocotyledonous habit in relation to morphology and anatomy. pp.7-20 in: Petaloid monocotyledons (eds. Brickell, C.D., Cutler, D.F. \& Gregory, M.) Academic Press: London. Distinctions between monocotyledons and dicotyledons; distribution, habitat, growth, architecture, root insertion, predators.

355. Traub, H.P. (1972) The order Alliales. Plant Life 28, 129-32. Proposes that this order should contain 3 families: Hesperocallaceae Traub, Milulaceae Traub and Alliaceae.

356. Traub, H.P. (1972) Genus Allium L.-Subgenera, sections and subsections. Plant Life 28, 132-7. All. Taxonomic, with some anatomical characters of leaf and bulb scales.

357. Traub, H.P. (1975) Class Liliida of Superclass Monocotyidra. Taxon 24, 453-60. Comparison of different systems of classification, e.g. those of Engler, Hutchinson, Cronquist, Takhtajan, Traub.

358. Uhring, J. (1973) Morphological studies of flower bud initiation and development in bulbous iris stored at various temperatures. J. Amer. Soc. Hort. Sci. 98, 54-61. Irid.

359. Utech, F.H. (1978) Floral vascular anatomy of Medeola virginiana L. (LiliaceaeParideae = Trilliaceae) and tribal note. Ann. Carnegie Mus. 47 (2), 13-28. [Biol. Abstr. 66 (1978) No. 19463.]

360. Utech, F.H. (1978) Comparison of the vascular floral anatomy of Xerophyllum asphodeloides (L.) Nutt. and $X$. tenax (Pursh) Nutt. (LiliaceaeMelanthioideae). Ann. Carnegie Mus. 47 (7), 147-67. [Biol. Abstr. 66 (1978) No. 56555.]

361. Utech, F.H. (1978) Floral vascular anatomy of Helonias bullata (LiliaceaeHelonieae), with a comparison to the Asian Heloniopsis orientalis. Ann. Carnegie Mus. 47 (8), 169-92. [Biol. Abstr. 66 (1978) No. 62947.]

362. Utech, F.H. (1978) Floral vascular anatomy of Pleea tenuifolia Michx. (LiliaceaeTofieldieae) and its reassignment to Tofieldia. Ann. Carnegie Mus. 47 (18), 423-54. [Biol. Abstr. 67 (1979) No. 7297.] Comparison with Tofieldia and Narthecium.

363. Utech, F.H. (1978) Floral vascular anatomy of the monotypic Japanese Metanarthecium luteoviride Maxim. (Liliaceae-Melanthioideae). Ann. Carnegie Mus. 47 (19), 455-77. [Biol. Abstr. 67 (1979) No. 7298.]

364. Utech, F.H. (1979) Floral vascular anatomy of Himalayan Theropogon pallidus Maxim. (Liliaceae-Convallarieae). Ann. Carnegie Mus. 48 (3), 25-41. [Biol. Abstr. 68 (1979) No. 13648.] Comparison with Convallaria.

365. Utech, F.H. (1979) Floral vascular anatomy of Scoliopus bigelovii Torrey (Liliaceae-Parideae = Trilliaceae) and tribal note. Ann. Carnegie Mus. 48 (4), 43-71. [Biol. Abstr. 68 (1979) No. 13647.] Comparison with Medeola.

366. Utech, F.H. \& Kawano, S. (1975) Biosystematic studies in Erythronium (Liliaceae-Tulipeae). I. Floral biology of E. japonicum Decne. Bot. Mag., Tokyo 88, 163-76.

367. Utech, F.H. \& Kawano, S. (1975) Biosystematic studies in Erythronium (Liliaceae-Tulipeae). II. Floral anatomy of $E$. japonicum Decne. Bot. Mag., Tokyo 88, 177-85.

368. Utech, F.H. \& Kawano, S. (1976) Biosystematic studies on Maianthemum (Liliaceae-Polygonatae). VIII. Floral anatomy of $M$. dilatatum, $M$. 
bifolium and M. canadense. Bot. Mag., Tokyo 89, 145-57.

369. Utech, F.H. \& Kawano, S. (1976) Biosystematic studies on Disporum (LiliaceaePolygonatae). III. Floral biology of $D$. sessile D. Don and $D$. smilacinum A. Gray from Japan. Bot. Mag., Tokyo 89, 159-71. Floral anatomy and floral UV patterns.

370. Utech, F.H. \& Kawano, S. (1976) Floral vascular anatomy of Convallaria majalis L. and C. keiskei Miq. (Liliaceae-Convallariinae). Bot. Mag., Tokyo 89, 173-82.

371. Utech, F.H. \& Kawano, S. (1980) Vascular floral anatomy of the Japanese Paris tetraphylla A. Gray (Liliaceae-Parideae). J. Phytogeog. Taxon. 28 (1) 17-23. Trill.

372. Vaikos, N.P., Markandeya, S.K. \& Pai, R.M. (1978) The floral anatomy of the Liliaceae: the tribe Aloineae. Indian J. Bot. 1, 61-8. Aloe, Gasteria, Haworthia.

373. Valsecchi, F. (1974) Osservazioni embriologiche, sistematiche ed ecologiche su Allium parciflorum Viv, G. bot. Ital. 108, 81-93. All.

374. Vasil, I.K. (1974) The histology and physiology of pollen germination and pollen tube growth on the stigma and in the style. pp.105-18 in: Fertilization in higher plants (ed. Linskens, H.F.) North-Holland Publ. Co.: Amsterdam \& Oxford. Includes Lili. Lilium. Transmitting tissue in style.

375. Venkateswarlu, J., Devi, P.S. \& Nirmala, A. (1980) Embryological studies in Eleutherine plicata Herb. and Belamcanda chinensis Lem. Proc. Indian Acad. Sci., B, 89, 361-7. [Bull. Signal., CNRS 370, 42 (1981) No. 6263.] Irid.

376. Venkateswarlu, J. \& Lakshmi, N. (1977) [1978] A contribution to the embryology of Crinum moorei L. Botanique 8, 61-8. [Bibl. Agric. 45 (1981) No. 001319.] Amar.

377. Ventner, A.M. (1972) 'n Morfologiese ondersoek van drie aalwyne. Aloe 10 (4), 49-96. [English summary 48.] Lili. Aloe, 3 taxa, leaf anatomy.

378. Wagner, P. (1977) Vessel types of the monocotyledons: a survey. Bot. Notiser 130, 383-402. Includes All., Amar., Haem., Hypox., Irid., Lili., Smil. Survey of literature and discussion of relationships. Roots, stems, leaves.

379. Werker, E. \& Fahn, A. (1975) Seed anatomy of Pancratium species from three different habitats. Bot. Gaz. 136, 396-403. Amar.

380. Werner, P.A. (1978) On the determination of age in Liatris aspera using crosssections of corms: implications for past demographic studies. Amer. Nat. 112, 1113-20. Lili. 'Growth rings' = bands of sclerenchyma.

381. Williams, R.F. (1975) The shoot apex and leaf growth. A study in quantitative biology. 256 pp. Cambridge Univ. Press. [Biol. Abstr. 60 (1975) No. 10948.] Includes Lili. Dianella.

382. Wilson, K. \& Anderson, G.J.H. (1979) Further observations on root contraction. Ann. Bot. 43, 665-75. Lili. Hyacinthus mainly, also Amar. Narcissus and Irid. Gladiolus. LM and TEM.

383. Yasui, K., Miyata, K. \& Konishi, K. (1974) [Histological studies on formation and thickening growth of gladiolus corms.] J. Jap. Soc. hort. Sci. 42, 371-9. [Japanese; English summary] Irid.

384. Yasui, K., Miyata, K., Kunisada, J. \& Konishi, K. (1974) [Histological studies on corm development in Freesia.] J. Jap. Soc. hort. Sci. 43, 150-60. [Japanese; English summary] [Bibl. Agric. 39 (1975) No. 151710.] Irid.

385. Yates, I.E. \& Duncan, W.H. (1970) Comparative studies of Smilax, Section Smilax of the southeastern United States. Rhodora 72, 289-312. Smil. Leaf anatomy of $8 \mathrm{spp}$.

386. Zahariadi, C. (1977) Notes on the intrageneric classification of the genus Ornithogalum L. (Liliaceae). Bot. Zh. SSSR 62, 1624-39. [Russian] Includes some characters of seed anatomy.

387. Zeiger, E. \& Cardemil, L. (1973) Cell kinetics, stomatal differentiation, and diurnal rhythm in Allium cepa. Dev. Biol. 32, 179-88. [Biol. Abstr. 56 (1973) No. 63158.] All. 
388. Zhestyanikova, L.L. \& Zykina, A.V. (1974) [Anatomical structure of succulent layers in the bulbs of some wild species of the genus Allium L.] Trudy. prikl. Bot. Genet. Selek. 51 (3), 136-47. [Russian; English summary.] All. 4 spp.

389. Zhestyanikova, L.L. \& Zykina, A.V. (1976) [Anatomical structure of the fleshy scales of the most widely distributed species of Allium.] Byull. Vses. Ord. Lenina Inst. Rast. N.I. Vavilova 64, 35-40. [Russian] All. 7 spp.

390. Zubkus, L.P. \& Sedel'nikova, L.L. (1977) [Anatomic and morphologic characteristics of juvenile-virgin plants of Erythronium sibiricum.] pp. 55-72 in: Dekorativnye rasteniia i ikh introduktsiia v zapadnuiu Sibir' (ed. Sobolevskaia, K.A.). [Russian] [Bibl. Agric. 42 (1978) No. 082180.] Lili. Seedling anatomy.

\section{ADDENDUM}

Since this survey was written in June 1981, many papers have been published. We list here a few of the more important ones.

Arroyo, S.C. (1982) Anatomia vegetativa de Ixiolirion Fisch. ex Herb. (Liliales) y su significado taxonomico. Parodiana 1: 271-86.

Behnke, H.-D. (1981) Siebelement-Plastiden, Phloem-Protein und Evolution der Blütenpflanzen: II. Monokotyledonen. Ber. dt. bot. Ges. 94, 647-62.

Brandham, P.E. \& Cutler, D.F. (1981) Polyploidy, chromosome interchange and leaf surface anatomy as indicators of relationships within Haworthia section Coarctatae Baker (Liliaceae-Aloineae). Jl. S. Afr. Bot. 47, 507-46.

Chakroun, S. \& Hébant, C. (1983) Developmental anatomy of Aphyllanthes monspeliensis, a herbaceous monocotyledon with secondary growth. $\mathrm{Pl}$. Syst. Evol. 141, 231-41.

Corneanu, G.C. \& Popescu, G.G. (1981) Distributional and anatomical studies on Fritillaria (Liliaceae) in Romania. Willdenowia 11, 307-15.

Cronquist, A. (1981) An integrated system of classification of flowering plants. Columbia Univ. Press: New York. $1262 \mathrm{pp}$.

Cutler D.F. (1982) Cuticular sculpturing and habitat in certain Aloë species (Liliaceae) from southern Africa, pp.425-44 in: The plant cuticle (eds. Cutler, D.F., Alvin, K.L. \& Price, C.E.). Academic Press: London.

Daghlian, C.P. (1981) A review of the fossil record of monocotyledons. Bot. Rev. 47, 517-55.

Dahlgren, R. \& Clifford, H.T. (1981) Some conclusions from a comparative study of the monocotyledons and related dicotyledonous orders. Ber. dt. bot. Ges. 94, 203-27.

Dahlgren, R.M.T. \& Clifford, H.T. (1982) The monocotyledons: a comparative study. Academic Press: London. $378 \mathrm{pp}$.

Eristavi, M.I. (1981) [Laminae foliorum specierum Caucasicarum generis Gladiolus L. structura anatomica.] Zam. Sist. Geog. Rast. 37, 35-41. [Russian]

Holloway, P.J. (1982) Structure and histochemistry of plant cuticular membranes: an overview. pp. 1-32 in: The plant cuticle (eds. Cutler, D.F., Alvin, K.L. \& Price, C.E.). Academic Press: London.

Moore, D.M., Arroyo, S.C. \& Doggett, M.C. (1982) The status of Phaeiophleps lyckholmi (Dusén) R.C. Foster (Iridaceae). Bot. J. Linn. Soc. 84, 103-13.

Kay, Q.O.N., Daoud, H.S. \& Stirton, C.H. (1981) Pigment distribution, light reflection and cell structure in petals. Bot. J. Linn. Soc. 83, 57-84.

Komar, G.A. (1982) [On the type of the ovule in some representatives of the subfamily Asphodeloideae (Liliaceae).] Bot. Zh. SSSR 67, 800-5. [Russian]

Naik, V.N. \& Nirgude, S.M. (1981) Vessels in Chlorophytum (Liliaceae). Bull. Mus. natn. Hist. nat., Paris, sér. 4, 3, Adansonia 201-12.

Oganezova, G.G. (1980) [Anatomic structure of Liliaceae seed and fruit envelopes with respect to family taxonomy. The subfamily Lilioideae sensu stricto.] 
Biol. Zh. arm. 33 (5), 487-95. [Russian; English summary] [Biol. Abstr. 72 (1981) No.787755.]

Oganezova, G.G. (1981) [Anatomical and morphological study in Ixiolirion tataricum ssp. montanum.] Bot. Zh. SSSR 66, 702-113. [Russian]

Oganezova, G.G. (1982) [On the anatomical structure of seed and fruit of some Liliaceae in connection with the systematics of the family. II. Scilloideae.] Bot. Zh. SSSR 67, 729-42. [Russian; English summary]

Simpson, M.G. \& Dickison, W.C. (1981) Comparative anatomy of Lachnanthes and Lophiola (Haemodoraceae). Flora 171, 95-113.

Sterling, C. (1982) Comparative morphology of the carpel in the Liliaceae: Veratreae. Bot. J. Linn. Soc. 84, 57-77.

Tanker, N. \& Kurucu, S. (1981) Leaf anatomy in relation to taxonomy in species of Allium found in Turkey. Q. Jl. crude Drug. Res. 19, 173-9.

Vaikos, N.P., Markandeya, S.K. \& Pai, R.M. (1981) The floral anatomy of the Liliaceae: the tribe Hemerocallideae. J. Indian bot. Soc. 60, 222-31.

Vos, M.P. de (1982) Die bou en ontwikkeling van die unifasisale blaar van Tritonia en verwante genera. Jl. S. Afr. Bot. 48, 23-37.

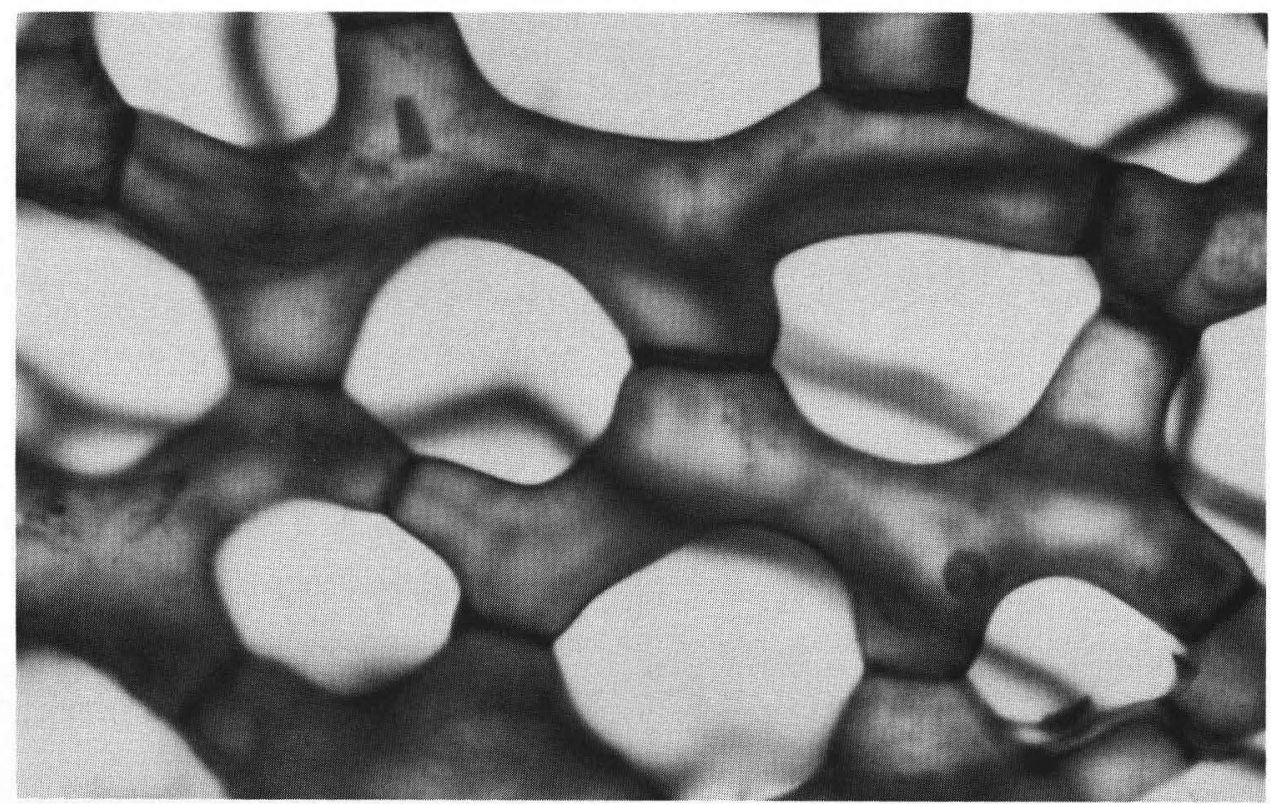

Fig. 1 Clintonia uniflora leaf, paradermal section showing shapes of chlorenchyma cells (x500). 


\section{INDEX TO REFERENCES IN BIBLIOGRAPHY}

\section{Bulb}

$6,9,10,12,13,16,25,26,28,33,34,42,98,100-102,116,125,126,145,159,167$, $187,222,223,225,226,264,267,279,289,291,319,326,356,388,389$.

Cell Inclusions (Plastids, Starch, Crystals)

$6,31,110,131,183,279,307,341,351,368,370$.

\section{Classification}

$3,13,31,62-64,67,75-77,79,128,146,147,169,215,287,332,345,346,355,357$.

\section{Corm}

$84,88-91,198,342,380,383,384$.

\section{Cuticle}

$10,19,21,22,30,40,41,44,52,68,69,70-72,117,141,153,157,158,218 \mathrm{a}, 234-237$, 276-278, 283, 323.

\section{Development}

$9,17,23-28,46,48-50,59,65,81-83,94,98,109,111-113,125,126,130,133,140$, $144,151,163,165,179,181,182,201,203,213,214,219,222,227,248,257,261$, $264,267,268,273,276,278,281,286,288,289,291,304,320,326,353,358,381,383$, $384,387,390$.

\section{Ecology}

$41,121,122,149,170,172,173,186,188,198,200,212,252,260,379$.

\section{Embryology}

$4,5,36-38,43,47,53,54,96,97,123,127,129,134-136,161,162,168,184,189$, $190,192,194,199,206-209,211,218,220,221,228-230,233,240,244-246,253$, $258,259,271,274,292,293,295-302,321,322,328,329,340,347-350,373,375,376$.

\section{Flower}

$4,18,42,51,59,61,65,74,78,79,86,92,99,130,132,134,138-141,148,151-153$, $163,181,193,194,196,210,217,224,226,238,239,243,249,266,269,270,281-285$, $288,294,305,308-318,323,330,343,347,351,352,358,359-371,372,374$.

\section{Leaf}

$1-5,7,8,10,11,13-16,19,21,22,29,34,40,41,44,48-50,66,68-74,85,87-91$, $95,111,114,115,117-122,124,131-133,142,143,149,154-156,158-160,164-166$, $170-173,183,185,186,188,200,205,206,214,222,225,227,231,232,234-239$, $248,256,260-262,275,283,285,290,320,325,327,331,335,342,344,356,377$, 381,385 .

\section{Medicinal}

4-6, 74, 210, 337, 338.

\section{Pathogen Resistance}

40, 117-120, 333.

\section{Phloem}

$31,106,109,178,180$.

\section{Physiological Anatomy}

$39,121,122,152,171,172,188,200,218 \mathrm{a}, 219,254,256,270,307,374$. 


\section{Rhizome}

$5,10,73,74,108,195,210,251$.

\section{Root}

$3-5,10,23,24,39,73,74,80,109,159,179,206,210,222,250,251,254,257,260$, $265,272,286,291,306,307,333,337,338,354,382$.

\section{Scanning Electron Microscopy (SEM)}

$10,19-22,30,40-42,44,61,68-72,110,140,141,152,153,157,158,186,188,191$, $234-237,241,242,266,272,276,277,283,291,323,348,351,352$.

\section{Seed \& Fruit}

$20,27,42,43,88,89,93,97,105,146,168,174-177,191,204,208,241,242,258$, $280,283,303,304,322,329,339,379,386$.

\section{Stem \& Inflorescence Axis}

$4,10,13,17,46,73,74,81-83,107,112,113,144,149-151,157,159,160,167,181$, $182,197,201,202,205,206,219,260,263,264,285,291,325,334,336,354,381$.

\section{Stomata}

$18,32,45,60,103,104,118,248,252,255,273,288,324,353,387$.

\section{Transmission Electron Microscopy (TEM)}

$23,24,31,38,39,78,109,110,122,138,139,141,171,172,176,187,218 \mathrm{a}, 233$, $254,270,276-278,284,348,351,352,382$.

\section{Xylem}

$55-58,247,378$. 